\title{
HACIA LA RECONSTRUCCIÓN DE LAS TENDENCIAS JURISPRUDENCIALES EN AMÉRICA LATINA Y EL CARIBE EN MATERIA DE IGUALDAD: SOBRE LA NO-DISCRIMINACIÓN, LA NO-DOMINACIÓNY LA REDISTRIBUCIÓNY EL RECONOCIMIENTO ${ }^{1}$

\author{
Laura Clérico, Liliana Ronconi e Martín Aldao
}

\section{RESUMO}

EL TRABAJO COMIENZA PRESENTANDO EL EXAMEN DE IGUALDAD EN SUS DISTINTAS VERSIONES; POR UNA LADO, COMO EXAMEN DE IGUALDAD FORMAL, POR EL OTRO LADO, COMO EXAMEN DE IGUALDAD MATERIAL, COMO ASÍ TAMBIÉN EN CLAVE DE IGUALDAD COMO MANDATO DE ANTI-SUBORDINACIÓN Y DESDE LAS PERSPECTIVAS DE LA REDISTRIBUCIÓN Y DEL RECONOCIMIENTO. LUEGO APLICA ESTAS HERRAMIENTAS ARGUMENTATIVAS PARA ANALIZAR SENTENCIAS DE VARIOS TRIBUNALES SUPERIORES DE LAS AMÉRICAS COMO ASÍ TAMBIÉN PRODUCCIONES DE LA COMISIÓN INTERAMERICANA DE DERECHOS HUMANOS Y SENTENCIAS DE LA CORTE INTERAMERICANA de Derechos Humanos, REFERIDAs a situaciones de DISCRIMINACIÓN BASADAS EN LA NACIONALIDAD, LA EDAD, LA SITUACIÓN DE DISCAPACIDAD, LA ORIENTACIÓN SEXUAL. EL ANÁLISIS DE LOS CASOS PRETENDE CONTRIBUIR A DETERMINAR CUÁL CONCEPCIÓN DE IGUALDAD PREVALECIÓ EN LA RESOLUCIÓN DE CADA CASO VISTO DESDE LA FUNDAMENTACIÓN DE LA SENTENCIA COMO ASÍ TAMBIÉN DE LAS MEDIDAS REPARATORIAS ORDENADAS. POR ÚlTIMO, EN LAS CONCLUSIONES CONJETURAMOS ACERCA DE LAS TENDENCIAS PREVALENTES EN MATERIA DE EXAMEN DE IGUALDAD EN LA REGIÓN.

\section{PALAVRAS-CHAVE}

IGUALDAD, CONCEPCIONES, NO-SUBORDINACIÓN, REDISTRIBUCIÓN, RECONOCIMIENTO.
TOWARDS A RECONSTRUCTION OF EQUALITY CASE-LAW TRENDS IN LATIN AMERICA AND THE CARIBBEAN: ON NON-DISCRIMINATION, ANTI-SUBORDINATION, REDISTRIBUTION AND RECOGNITION

\section{ABSTRACT}

THE ARTICLE BEGINS BY 1) PRESENTING THE READER TO SOME GENERALITIES CONCERNING THE EQUALITY TEST (THE CONCEPT OF FORMAL EQUALITY AND SUBSTANTIVE EQUALITY IN TERMS OF ANTISUBORDINATION AND THE PERSPECTIVES OF REDISTRIBUTION AND RECOGNITION). IT THEN REVIEWS DECISIONS FROM A NUMBER OF LATIN AMERICAN COUNTRIES' HIGH COURTS AS WELL AS OTHERS RENDERED BY THE INTER AMERICAN COMMISSION ON HUMAN RIGHTS (I/A CHR) AND THE INTER-AMERICAN COURT OF HUMAN RIGHTS (IA COURT HR) RELATED TO DISCRIMINATION BASED ON NATIONALITY, AGE, DISABILITY, AND SEXUAL ORIENTATION. THE ANALYSIS OF THE CASES SHALL CONTRIBUTE TO DETERMINE THE CONCEPT OF EQUALITY THAT PREVAILS IN EACH DECISION (AS EVIDENCED IN THE GROUNDS PROVIDED BY THE JUDGE AS WELL AS IN THE REMEDIES AWARDED). FINALLY WE ATTEMPT TO DRAW SOME CONCLUSIONS OVER THE PREVAILING TREND IN THE REGION CONCERNING EQUALITY.

\section{KEYWORDS}

EQUALITY, CONCEPTIONS, ANTI-SUBORDINATION, REDISTRIBUTION, RECOGNITION.

\section{INTRODUCCIÓN}

Un sinnúmero de trabajos académicos, informes de Organismos Internacionales de Protección de los Derechos Humanos, de Organizaciones No-Gubernamentales y Organizaciones de Base, dan cuenta de un diagnóstico común: América Latina y el Caribe es 
un territorio marcado por profundas desigualdades sociales y político-económicas ${ }^{2}$ leídas tanto en clave de distribución como de falta de reconocimiento. ${ }^{3}$ Esta desigualdad persiste pese a mayores (o menores) esfuerzos que se han intentado por medio de políticas públicas para atender a las formas más extremas de la desigualdad. Como leen algunos cientistas sociales: "los datos disponibles indican que el crecimiento ha sido errático y no ha alcanzado los parámetros esperados, que los empleos que se han generado no han sido suficientes ni de buena calidad como para tener el impacto social esperado. En este contexto, ni la pobreza ha sido disminuida de manera estructural, ni la vulnerabilidad social ha sido regulada de manera efectiva, a través de esquemas eficientes de seguridad social, ni la exclusión social, a la que ha sido sometido históricamente los indígenas o los afrodescendientes, ha sido ya no digamos erradicada, ni siquiera reducida de manera significativa." 4

Por su parte, varias de las Constituciones e Instrumentos Internacionales de Derechos Humanos vigentes en la región identifican a los "grupos desaventajados" que padecen la situación de desigualdad fundada en una distribución asimétrica del poder. Incluso, varios de esos instrumentos normativos reconocen - expresa o implícitamente- que de la situación de dominación estructural no se puede salir en forma individual sino que se requieren medidas de acción positiva reparadoras o transformadoras para lograr igualdad real de condiciones para el ejercicio de los derechos.

Por esto, el objetivo de este trabajo ${ }^{5}$ es establecer la medida en que la jurisprudencia de los tribunales superiores y constitucionales de la región puede ser reconstruida como un indicador de la receptividad (o no) del enfoque de la desigualdad estructural. Partimos del supuesto de que la fórmula dominante del examen de igualdad sigue siendo la del principio de igualdad como no-discriminación, que a nuestro entender se queda a mitad de camino para responder a la demanda de igualdad en el contexto latinoamericano. Así, sostenemos que es necesario ampliar la fórmula de igualdad como principio de no-dominación o no-sometimiento. ${ }^{6} \mathrm{Sin}$ embargo, la inclusión de la perspectiva de igualdad como no-dominación o nosometimiento es insuficiente si no nos preguntáramos por las causas que generan esa desigualdad. Por esto, proponemos ampliar la mirada para comprender que la desigualdad no solo deviene de una distribución injusta de los bienes económicos y sociales ${ }^{7}$ sino también del reconocimiento. ${ }^{8}$ Recién con esta última ampliación de las miradas estaríamos en condiciones de analizar con detenimiento los casos llegados a la Cortes y Tribunales de diversos Estados de América Latina y el Caribe sobre desigualdad por razón de pobreza, de nacionalidad, de etnia, de la situación de discapacidad, de la edad o de la orientación social —excluimos la jurisprudencia en materia de género o de pueblo o comunidades originarias. Por último realizaremos unas consideraciones finales que aspiramos sean leídas en claves de preguntas para formular mejores hipótesis en la lucha por la igualdad en América Latina y el Caribe. 


\section{Concepciones de igualdad 9}

La igualdad de todos los ciudadanos constituye una condición de posibilidad o un presupuesto de todos los sistemas jurídicos modernos. ${ }^{10}$ No obstante, pretender definir la igualdad se presta a una serie de problemas e inconvenientes conceptuales. En primer lugar, debe distinguirse la igualdad en el sentido de uniformidad - como predicaríamos de un conjunto de objetos producidos en serie-- de la igualdad como equidad o imparcialidad — como predicaríamos de una sociedad que no tuviese privilegios- - Pero aún superada esta ambigüedad semántica, tenemos que aceptar que un privilegio o un trato desigual nunca pueden ser definidos en abstracto sino siempre en el contexto de una sociedad determinada, puesto que aquello que puede ser considerado igualitario en algún rincón del planeta puede no serlo en otro. Pero aún si buscásemos la imparcialidad, en el marco de una temporalidad y una sociedad determinadas, aún tendríamos que reconocer que ninguno de nosotros como individuo puede definir lo que otros individuos deben aceptar como igualitario - o justo, o imparcial — sin caer en la pretensión dogmática de tener un acceso privilegiado a la idea de justicia, lo que de por sí implicaría ubicarnos por encima del resto en términos morales o, en otros términos, buscar la igualdad partiendo de la afirmación de un privilegio originario. Es así que entendemos no solo que resulta imposible resolver en abstracto todas las paradojas que genera la idea de igualdad sino también que pretender avanzar en este sentido carece de sentido. Como afirma R. de Giorgi, el principio de igualdad tiene en el derecho moderno la forma de una expectativa, o una pretensión, que de ningún modo puede resolver el derecho por sí mismo, ${ }^{11} \sin$ la participación o el involucramiento de ciudadanos y operadores jurídicos, que llenen de contenido las estructuras autorreferenciales del ordenamiento jurídico. Es que solo los sujetos de derecho pueden decidir si esa expectativa ha sido alcanzada. Es en este punto que entran en liza las formas de la argumentación.

Aun cuando todo examen de igualdad implica siempre una comparación entre personas en orden a determinar (a) si se está vulnerando una situación de igualdad, a través del trato diferenciado de personas que se encuentran en la misma condición, o bien (b) si se está perpetuando una desigualdad, otorgando el mismo trato a personas que se encuentran en distinta condición; no debe perderse de vista que el centro del examen de igualdad no es la diferencia en sí misma sino la evaluación de las razones (o sinrazones) que hablan a favor o en contra del trato idéntico o diferenciado. ${ }^{12}$ En este sentido, cuanto más público sea el debate, cuanto más difundidas se encuentren estas discusiones, cuanto más se repliquen a través de la sociedad — de modo que la discusión entre individuos retroalimente la discusión de los parlamentarios y de los jueces_- más posibilidades habrá de que cada ciudadano pueda, desde su posición, conocer y evaluar las razones en las que se apoya su propia idea de igualdad, así como también las razones en las que se sustentan las ideas de igualdad que difieren de la suya. Es en este sentido que entendemos que una sistematización de las 
principales estructuras argumentativas utilizadas para discutir el problema de la igualdad permite avanzar en la sistematización y simplificación de este intercambio de valores e intereses que es la producción del derecho en democracia.

\section{I IGUALDAD FORMAL Y MATERIAL}

La fórmula de igualdad formal se limita a verificar que aquellos que pertenecen a la clasificación realizada por el legislador sean tratados de la misma manera. Es la versión más débil del examen de igualdad y nada dice acerca de las razones en las que se apoya la clasificación, ni acerca de cómo deben ser tratados qué individuos con qué propiedades. ${ }^{13}$ Esta concepción de la igualdad es la que se encuentra detrás de las criticadas - y con razón — fórmulas de "igualdad entre los iguales" y de "separados pero iguales", que ha servido como una forma de disimular el repudio hacia grupos excluidos y que divorcia el principio de igualdad del de no-discriminación, al dejar que el Estado determine la fórmula de igualdad que será fuente de derechos, clausurando todo reclamo judicial contra éstas decisiones.

La insuficiencia de esta fórmula de igualdad para dar cuenta del trato discriminatorio en sus múltiples formas ha conducido al desarrollo de la fórmula de la igualdad jurídica material, que se pregunta por la legitimidad del criterio de clasificación y por las razones de la selección operada por el legislador. La fórmula de igualdad jurídica material dice que no se viola el mandato de igualdad si: a todos los que se encuentran en igualdad de circunstancias relevantes se los trata de igual forma. ${ }^{14} \mathrm{En}$ suma, y como reitera la Corte IDH, es discriminatoria toda distinción que carezca de justificación objetiva y razonable. ${ }^{15}$ La razonabilidad de la justificación se ve sujeta, en la región, a lo que llamaremos un examen integrado, en la medida en que retoma el principio de proporcionalidad de la jurisprudencia europea y la mayor o menor intensidad en el examen, característica propia del enfoque norteamericano. ${ }^{16}$ De este modo, la aplicación de la proporcionalidad en el examen de igualdad ayuda para determinar si el criterio de distinción que genera las categorías o grupos (medida estatal) tiene relación con las finalidades (razones) de la norma. ${ }^{17}$ El subexamen de idoneidad se pregunta si el medio logra promover los fines estatales y si no los logra entonces ya tenemos una primera razón que habla en contra del trato desigualitario. El subexamen de medios alternativos dice que las razones de la distinción no son suficientes si pudo haberse evitado el trato desigualitario a través de la implementación de algún otro medio alternativo (es decir, uno que evite esa clasificación). El subexamen de proporcionalidad en sentido estricto supone determinar la intensidad de restricción a la igualdad y a los derechos que produce la clasificación y, por el otro lado, determinar el peso de las razones que hablan a favor de la clasificación y de la promoción del fin estatal. Por ello, no hay razones suficientes para la distinción si la intensidad de restricción es mayor que el peso de las razones justificatorias. A su vez, dependiendo de las circunstancias del caso, estos tres exámenes pueden ser aplicados con diversa 
intensidad, en una escala que va desde el examen de mera racionalidad, pasando por el escrutinio intermedio, hasta llegar al escrutinio estricto.

El examen de igualdad de mera racionalidad presume la legitimidad o constitucionalidad de la clasificación realizada por el legislador. Esto significa que la carga de la argumentación la tiene quien realiza el reclamo igualitario y solo se declarará la clasificación y sus efectos como arbitrarios si este logra argumentar que no existe relación alguna entre medio y fin y que esa falta de relación justificatoria es evidente y manifiesta; de lo contrario se confirma la presunción a favor de la legitimidad de la clasificación.

El escrutinio intermedio exige una relación más sustancial entre clasificación, criterio de clasificación, efectos de la clasificación y razones justificatorias; la relación tiene que ser plausible, es decir, debe demostrarse una relación estrecha entre clasificación y razones justificatorias y alegarse algún fin estatal importante que justifique la clasificación.

El más exigente de los exámenes es el escrutinio estricto ${ }^{18}$ Este presume la falta de justificación de la discriminación; por lo cual la carga de la argumentación se traslada en cabeza de aquellos que alegan la justificación de la clasificación, por lo general, el Estado. Implica además una exigencia agravada de justificación: la arbitrariedad solo puede ser revertida si quien tiene la carga de la argumentación logra alegar y justificar razones más que importantes — por ejemplo, un fin estatal imperioso más que urgente - y que no existía ningún otro medio alternativo que pudiera evitar la clasificación. En el escrutinio estricto puede hablarse además de una regla epistémica, que dice que si persisten dudas al final de la argumentación, tanto la clasificación como sus efectos deben ser considerados como arbitrarios. ${ }^{19}$

La Corte Constitucional Colombiana ha sistematizado los siguientes criterios para la aplicación del escrutinio estricto cuando: (a) está de por medio una clasificación sospechosa como las enumeradas en forma no taxativa a manera de prohibiciones de discriminación en la Constitución (agregamos, o en los Instrumentos Internacionales de Derechos Humanos); (b) la medida recae principalmente sobre personas en condiciones de debilidad manifiesta, grupos marginados o discriminados, sectores sin acceso efectivo a la toma de decisiones o minorías insulares y discretas; (c) la medida que hace la diferenciación entre personas o grupos afecta prima facie gravemente el goce de un derecho constitucional fundamental; o (d) se examina una medida que crea un privilegio. ${ }^{20}$

A su vez las categorías señaladas como sospechosas son aquellas que: (i) se fundan en rasgos permanentes de las personas, de los cuales éstas no pueden prescindir por voluntad propia a riesgo de perder su identidad; (ii) han estado sometidas, históricamente, a patrones de valoración cultural que tienden a menospreciarlas; y (iii) no constituyen per se criterios que permitan efectuar una distribución o reparto racional y equitativo de bienes, derechos o cargas sociales. 


\section{I.2 IGUALDAD COMO NO-DOMINACIÓN O NO-SOMETIMIENTO:}

REDISTRIBUCIÓN Y RECONOCIMIENTO

Hemos visto que el examen de igualdad jurídica material desarrolló escrutinios bien exigentes, sin embargo, no resultan ser herramientas argumentativas lo suficientemente potentes para conmover un status quo fuertemente desigualitario. Es decir, un status quo en el que la desigualdad no es solo puntual o individual sino que responde a una práctica sistemática de desigualdad, de dominación, y que, como vimos en la introducción, se encuentra firmemente arraigada en los orígenes de los estados regionales, determinando la discriminación sistemática de sectores completos de la sociedad. ${ }^{21}$ Así R. Saba afirma que esta se produce “(c)omo resultado de una situación de exclusión social o de 'sometimiento' de estos grupos por otros que, en forma sistemática y debido a complejas prácticas sociales, prejuicios y sistemas de creencias, desplazan a mujeres, discapacitados, indígenas u otros grupos de personas de ámbitos en los que ellos se desarrollan o controlan”. ${ }^{22}$ Esta desigualdad no es natural sino que surge como producto de una estructuración social dada. ${ }^{23}$ Para que estos grupos desaventajados puedan ejercer sus derechos en condiciones de igualdad, se deben dictar medidas de acción positiva. ${ }^{24}$

Ahora bien, estas medidas de acción positiva implican, en ciertas condiciones, la redistribución ${ }^{25}$ de bienes económicos y sociales, con el fin de quebrar el círculo vicioso que implica que aquellos con menos acceso a recursos materiales tendrán menos posibilidades de cuestionar la distribución de los mismos. En este caso se trata de atacar la desigualdad socioeconómica arraigada en la estructura político-económica de la sociedad respecto de la distribución de bienes (ejemplos de este tipo de injusticia se pueden vislumbrar en la explotación laboral, la marginación económica, la privación de los bienes materiales indispensables para llevar una vida digna, entre otros). Así la CIDH ha dicho que

(l) a capacidad de participar en la sociedad conlleva derechos civiles y políticos, conjuntamente con derechos económicos, sociales y culturales.

De ello se desprende que, sin progreso en el área de los derechos económicos y sociales, los derechos civiles y políticos, logrados con gran esfuerzo y sacrificio humano, siguen siendo una mera aspiración para los sectores de menos recursos y más bajo nivel de educación. En última instancia, la consolidación de la democracia representativa, meta de todos los Estados miembros, comporta el ejercicio de una participación plena por parte de todos los integrantes de la sociedad. ${ }^{26}$

Ahora bien, la desigualdad por dominación o sometimiento deviene no solo de una distribución injusta de los bienes económicos y sociales sino también del reconocimiento. ${ }^{27}$ Por ello, las desigualdades no siempre pueden reducirse a la existencia de 
una brecha económica, y por ende no siempre la inyección de recursos materiales constituye una solución adecuada. En este caso, la desigualdad no aparece planteada en términos de pobres y ricos sino de identidades dominantes e identidades dominadas. Esta clase de discriminación, practicada históricamente sobre mujeres, afrodescendientes, pueblos originarios, miembros del colectivo de Lesbianas, Gays, Bisexuales y Trans (en adelante, LGBT), entre otros, requiere de medidas de acción positiva que impliquen el reconocimiento de estas identidades diversas. Ahora bien, a diferencia del resto de las fórmulas de igualdad, ésta no puede ser resuelta sin introducir la voz de los afectados. Esta fórmula de igualdad implica, por un lado, un examen sobre la promoción de la medida de acción positiva, en tanto que no cualquier medida estatal tendiente a paliar la desigualdad será considerada adecuada o suficiente. ${ }^{28}$ En caso de que la medida no fuera suficiente mediante el examen, surge lo que le queda al Estado por hacer en clave de acción positiva.

Por otro lado, solo esta fórmula de igualdad puede abrir los ojos a situaciones de discriminación estructural, las que necesariamente son invisibles desde la perspectiva predominante en la sociedad: Ninguna concreción del principio de igualdad puede ser considerada válida de modo definitivo, en un contexto democrático, sin la participación de aquellos que se encuentran en la situación concreta de disparidad, como es el caso en el contexto interamericano de los pueblos o comunidades indígenas, los afrodescendientes, las personas con discapacidad, las personas en situación de pobreza o indigencia, los niños o las niñas, las personas ancianas, las mujeres, los migrantes, entre otros.

\section{La igualdad en la JURisprudencia de América Latina y el Caribe}

Las cortes supremas o constitucionales y los tribunales de varios estados de América Latina y el Caribe aplican el mandato de igualdad se diría desde que nacieron como instituciones. Sin embargo, probablemente recién a partir de las últimas décadas del siglo XX empezaron a aplicar la máxima de igualdad como igualdad jurídico material y en la versión del principio de no-discriminación. Incluso esta tendencia se vio fortalecida cuando varias Constituciones cobijaron el Derecho Internacional de los Derechos Humanos. Desde hace algunos años se observa una mayor cantidad de jurisprudencia que analiza las situaciones de desigualdad desde la concepción de la igualdad como no-dominación; aunque, por ahora, esta no sea la tendencia dominante, es probable que siga creciendo en presencia si es que los tribunales se siguen interpretando también como lugares en los que se pueden plantear reclamos para provocar discusiones que implican transformaciones estructurales.

A continuación trabajamos con detenimiento jurisprudencia de diversos tribunales superiores de Estados de América Latina y el Caribe sobre igualdad. Esta jurisprudencia será clasificada según que la situación de desigualdad se origine en: 
(a) la nacionalidad, (b) la etnia, (c) la edad, (d) por la discapacidad, (e) la orientación sexual y (f) la pobreza o indigencia.

Cabe advertir que si bien trabajaremos en forma particular estas categorías de discriminación más corrientes en el ámbito latinoamericano, no olvidamos que en la mayoría de los casos las discriminaciones no se producen por una sola causa sino que existe una pluralidad de causas. Hablamos en estos casos de discriminación múltiple o discriminación intersectorial. De esta manera, los grupos discriminados padecen una situación compleja que afecta distintos aspectos de su vida (social, educativo, laboral, etc.) que no es fácil revertir, tornándose insuficiente las políticas públicas unidireccionales (es decir, aquellas que atacan solo una de las causas de discriminación), pues se requieren políticas integrales que erradiquen la desigualdad en todos sus aspectos. En este sentido, sostuvo el Comité de Derechos Económicos, Sociales y Culturales en la Observación General 20 que "algunos individuos o grupos sufren discriminación por más de uno de los motivos prohibidos, por ejemplo las mujeres pertenecientes a una minoría étnica o religiosa. Esa discriminación acumulativa afecta a las personas de forma especial y concreta y merece particular consideración y medidas específicas para combatirla”.29

Así, por ejemplo, las mujeres padecen una "doble victimización ante las vicisitudes de 'la naturaleza' (reproducción, gestación, enfermedades) y ante los varones (violencia, ejercicio irresponsable de su sexualidad)". 30 Sin embargo, las causas pueden aumentar cuando se trata, por ejemplo, de mujeres indígenas o afrodescendientes.

\section{I NACIONALIDAD, MIGRANTES}

El contexto de América Latina y el Caribe presenta un panorama diverso relacionado con la movilidad de personas por el territorio de los diversos Estados, léase personas "extranjeras", personas "migrantes". A fines del siglo XIX y comienzos del siglo XX encontraban a Argentina, Uruguay, Brasil, Estados Unidos como países receptores de inmigración masiva. Los países receptores comenzaron en uso de su "soberanía" estatal a aprobar normas que restringían los derechos de las personas extranjeras que residían en sus territorios - a pesar de que algunas de Constituciones de esos Estados proclamaban los mismos derechos a todas las personas extranjeras residentes en sus territorios (por ejemplo, art. 20 de la Const. Argentina). En este contexto particular surgen los reclamos de algunas personas extranjeras frente a situaciones puntuales de discriminación. Así la Corte Suprema de Justicia argentina declaró la inconstitucionalidad de una norma provincial que exigía la nacionalidad argentina para ejercer la docencia en un establecimiento privado con reconocimiento oficial de nivel pre-escolar en el caso de una residente de los Estados Unidos que había estudiado en Argentina y tenía título habilitante para el ejercicio de esa profesión. ${ }^{31}$ Esta jurisprudencia se reitera -aunque con leves matices - cuando esa misma Corte declara la inconstitucionalidad de un artículo de 
una ley de la Provincia de Córdoba que exigía la nacionalidad argentina para ingresar como personal permanente al régimen del "equipo de salud humana" de un hospital público. La actora residente en Argentina de nacionalidad española había trabajado por varios años en el mismo Hospital como psicóloga (de manera no remunerada y cubriendo suplencias), pero sin un cargo permanente. La Corte Suprema argentina exigió a la luz del principio general que consagra el art. 16 de la Constitución argentina en favor de todos los habitantes y el reconocimiento pleno de los derechos de los extranjeros al ejercicio de su profesión (art. $20 \mathrm{CN}$ ), "una justificación suficiente de la restricción consagrada en la ley" (provincial). Esta justificación agravada no fue satisfecha por el Estado local, que se limitó a "una dogmática afirmación de su postura que excluye la acreditación de su razonabilidad o del interés estatal que la ampare". ${ }^{32}$ Esta jurisprudencia se reitera pero con un examen de igualdad más analítico y estricto en el caso "Gottschau".

En el caso "Gottschau"33 la Corte Suprema de Argentina resolvió respecto de la (in)constitucionalidad de una norma de la Ciudad Autónoma de Buenos Aires que establecía el requisito de la nacionalidad argentina para acceder a un empleo público. Evelyn Gottschau, de nacionalidad alemana, pero radicada en Argentina desde 1983, lugar donde cursó sus estudios secundarios y universitarios (abogada), se postuló en el concurso de secretarios de primera instancia del Poder Judicial de la Ciudad Autónoma de Buenos Aires. Su solicitud fue denegada en virtud de un artículo del Reglamento de Concursos (Acta 24/99). ${ }^{34}$ La Corte Suprema argentina resolvió el caso aplicando el examen de igualdad estricto. La cuestión, sostuvo la Corte, radica en establecer si el requisito de la nacionalidad para acceder a un empleo público (en el caso, secretario de juzgado) forma parte de la idoneidad a la que se refiere el art. $16 \mathrm{CN}$ argentina. Con cita del caso Hooft, ${ }^{35}$ sostuvo que "cuando se impugna una categoría infraconstitucional basada en el origen nacional... corresponde considerarla sospechosa de discriminación y portadora de una presunción de inconstitucionalidad que corresponde a la demandada levantar”. A su vez agregó que esta presunción de inconstitucionalidad "solo se podía levantar [...] con una cuidadosa prueba sobre los fines que había intentado resguardar y sobre los medios que había utilizado al efecto. En cuanto a los primeros, deben ser sustanciales y no bastará que sean meramente convenientes. En cuanto a los segundos, será insuficiente una genérica 'adecuación' a los fines sino que deberá juzgarse si los promueven efectivamente y, además, si no existen otras alternativas menos restrictivas para los derechos en juego que las impuestas por la regulación cuestionada”. Respecto del caso particular, indicó el Tribunal que en tanto el cargo de secretario de juzgado no implica ejercer funciones de jurisdicción la medida no resulta adecuada ni necesaria, pues existían otras alternativas como la extensión de la residencia, el lugar donde se cursaron los estudios, etc., para demostrar la idoneidad. Así la Corte declara la inconstitucionalidad de la medida y ordena el dictado de 
una nueva sentencia. En este caso, entonces la Corte deja en claro que cuando se trata de empleo público pero que no implican del ejercicio de la jurisdicción (¿funciones esenciales del Estado de derecho?) la distinción entre nacionales y extranjeros no está fundamentada. Las dudas giran respecto de las distinciones que surgen en relación con los cargos vinculados a las funciones "esenciales" del Estado. En un artículo sobre el requisito de nacionalidad, Guillermo Treacy propone que respecto de los

empleos en el sector público que impliquen el ejercicio directo y personal de funciones estatales (vgr., la jurisdicción, cargos diplomáticos, militares, altos cargos en la Administración Pública)... podría aplicarse el examen de mera razonabilidad. Podría darse como fundamento la importancia de los cargos —aunque este criterio es relativo-_, como así también el hecho de que tales funcionarios tienen capacidades decisorias, que podrían comprometer la voluntad del Estado y acarrear, inclusive, su responsabilidad internacional. 36

En general la Corte argentina aplica en los casos en los que las normas o los actos clasifican en perjuicio de los derechos de los extranjeros un examen de igualdad jurídica material de escrutinio estricto y declara la inconstitucionalidad de la norma atacada. Sin embargo, en ninguno de estos casos se deja vislumbrar un planteo de fondo de la situación de los extranjeros o migrantes en Argentina que suelen padecer situaciones de desigualdad estructural. ${ }^{37}$ Así, los casos llegados a la Corte parecen responder tanto en los planteos como en la resolución a cuestiones puntuales (una lectura distinta podría hacerse del caso "Reyes Aguilera" que será tratado en un apartado posterior de este trabajo). Un caso puntual de discriminación parece ser también de la sentencia C-1058/03 de la Corte Constitucional Colombiana que confirmó la constitucionalidad del art. n. 473 del Código de Comercio sobre la exigencia de origen nacional del representante de toda sociedad extranjera que tuviere por objeto explotar, dirigir o administrar un servicio público (en Colombia). La demandante consideró que dicha norma, al impedirle a los extranjeros ser representantes de las sociedades extranjeras que tengan esa finalidad, es contraria a la garantía de igualdad, prevista en los arts. 13 y 100 de la Constitución Colombiana. ${ }^{38}$ La Corte reiterando su jurisprudencia estableció que el art. 13 impone un principio general de no-discriminación. Sin embargo, ese principio no es absoluto. El art. 100 permite la restricción o no reconocimiento de algunos derechos civiles a los extranjeros siempre que exista una causa de justificación por razones de orden público. "Dichas restricciones deben ser expresas, necesarias, mínimas y estar dirigidas a la realización de finalidades constitucionales legítimas" (cons. 4.2). En el caso particular, la Corte considera que al tratarse de sociedades que tienen en sus manos el funcionamiento de los 
servicios públicos — servicios que "son inherentes a la finalidad social del Estado" y que "se proyectan a cubrir necesidades básicas insatisfechas..." (cons. 4.3) - sumado al "impacto social y económico de las decisiones que pueden llegar a tomar las personas que ejerzan estos cargos [...], puede ser de tal magnitud que se afecte el orden público, aspecto este que fundamenta la restricción impuesta a los extranjeros en estos casos".

Todos estos casos hablan de la aplicación del principio de no-discriminación que atiende a desigualdades puntuales e individuales. En general, los casos que se han presentado respecto a distinciones fundadas en la nacionalidad ${ }^{39}$ no implican discriminación a un grupo afectado por una desigualdad estructural. ${ }^{40}$ Se diría tal vez que los reclamantes de todos estos casos no pertenecen a grupos de migrantes que se encuentran en una situación de desigualdad estructural por su condición de tal y/o de indigencia y/o de pobreza. Latinoamérica y el Caribe no solo se caracteriza por ser "exportadora" de más de 25 millones de personas sino que, además algunos de esos países son receptores de más de 6 millones de migrantes intra-regionales, a estas hay que sumar las personas que piden asilo o refugio y provienen de África o Asia, y las que se encuentran en tránsito en Centroamérica hacia los Estados Unidos de América. ${ }^{41}$ Esto involucra otra cuestión relevante de estudiar en la región: los migrantes intra-regionales que padecen diferentes discriminaciones en los países receptores.

Respecto de la situación migrantes la Corte $\mathrm{IDH}^{42}$ sostuvo como principio general que:

Se debe señalar que la situación regular de una persona en un Estado no es condición necesaria para que dicho Estado respete y garantice el principio de la igualdad y no-discriminación, puesto que [...] dicho principio tiene carácter fundamental y todos los Estados deben garantizarlo a sus ciudadanos y a toda persona extranjera que se encuentre en su territorio [...]. Lo importante es que, al tomar las medidas que correspondan, los Estados respeten sus derechos humanos y garanticen su ejercicio y goce a toda persona que se encuentre en su territorio, sin discriminación alguna por su regular o irregular estancia, nacionalidad, raza, género o cualquier otra causa (cons. 118). ${ }^{43}$

El desafío tiene que ser leído en clave de no-dominación. Como advierten Asa y Ceriani Cernadas, el desafío creciente es para los países de origen como para las sociedades de acogida de migrantes. "La respuesta de los Estados, especialmente de destino, debe tener muy presente las necesidades y derechos de este grupo social. Las normas y las políticas públicas deben adecuarse a estos desafíos, pero no para arbitrar mecanismos de represión y discriminación sino para identificar las medidas 
más apropiadas para proteger sus derechos, interpretando los tratados internacionales de manera dinámica y progresiva”. ${ }^{44}$ En este sentido, cabe preguntarse en qué medida la jurisprudencia interna puede ser un canal adecuado para plantear reclamos de igualdad. Al respecto el caso paradigmático parece ser el de las niñas haitianas con residencia en República Dominicana llegado hasta la Corte IDH, que trabajaremos a continuación. Por lo demás, no suelen llegar gran cantidad de casos a los estrados judiciales aunque organismos públicos y ONGs informen sobre las situaciones de discriminación y de dominación que padecen varios grupos de migrantes en la región. ${ }^{45}$

En este sentido, por ejemplo, en República Dominicana padecen una situación de discriminación los haitianos y descendientes de haitianos que suelen ser trabajadores de la caña de azúcar. ${ }^{46}$ La Corte IDH se pronunció en el caso de las niñas Yean y Bosico vs. República Dominicana por una petición presentada ante la CIDH en favor de las niñas Dilcia Yean y Violeta Bosico contra la República Dominicana. Para comprensión de la petición, hay que detenerse en que las madres haitianas suelen dar a luz a sus hijos en sus casas en República Dominicana, dada la dificultad que tienen para trasladarse desde los bateyes hasta los hospitales de las ciudades, la escasez de medios económicos, y el temor de presentarse ante los funcionarios de un hospital, de la policía o de la alcaldía "pedánea" y ser deportados. Esto conlleva a que los haitianos y dominicanos de ascendencia haitiana recurran al procedimiento de declaración tardía de nacimiento para declarar a sus hijos nacidos en la República Dominicana. En el caso de las niñas Yean y Bosico, el Estado negó la nacionalidad, solicitada mediante el procedimiento de declaración tardía, a pesar de haber nacido en territorio dominicano. La falta de reconocimiento de la nacionalidad ponía a las niñas en una situación de peligro inminente de ser expulsadas del país; además, no podían ingresar a la escuela ni acceder a servicios de salud y asistencia social por carecer de un documento de identidad. El caso fue sometido a la Corte IDH. La Corte resolvió que el Estado Dominicano violó los derechos a la adopción de medidas de protección, a la igualdad y no-discriminación, a la nacionalidad, a la personalidad jurídica y al nombre de las niñas al negarse a emitir los certificados de nacimiento e impedirles el ejercicio de derechos de ciudadanía debido a su ascendencia. La Corte estableció que "la importancia de la nacionalidad reside en que ella, como vínculo jurídico político que liga una persona a un Estado determinado, permite que el individuo adquiera y ejerza los derechos y responsabilidades propias de la pertenencia a una comunidad política. Como tal, la nacionalidad es un prerrequisito para el ejercicio de determinados derechos”. En consecuencia, ordenó al Estado la adopción de medidas para revertir la situación de discriminación histórica en sus sistemas de registro de nacimientos y su sistema educativo y, en particular, la adopción de un procedimiento sencillo, accesible y razonable, para que los niños dominicanos de ascendencia haitiana obtengan su certificado de nacimiento. En este sentido, sostuvo que para la inscripción tardía de nacimiento, el Estado 
deberá tomar en cuenta la situación especialmente vulnerable de los niños dominicanos de ascendencia haitiana. Los requisitos exigidos no deben constituir un obstáculo para obtener la nacionalidad dominicana y deben ser solamente los indispensables para establecer que el nacimiento ocurrió en la República Dominicana. Al respecto, la identificación del padre o de la madre del niño no puede estar limitada a la presentación de la cédula de identidad y electoral sino que el Estado debe aceptar, para tal fin, otro documento público apropiado, ya que la referida cédula es exclusiva de los ciudadanos dominicanos. ${ }^{47}$

Este caso resulta paradigmático por dos cuestiones. Por un lado, la Corte IDH no solo reconoce la situación de dominación que padecen los niños haitianos o dominicanos con ascendencia haitiana sino que ordena al Estado tomar medidas de acción positiva. En este sentido, si se leen las medidas reparatorias (apartado C de la sentencia de la Corte IDH), se puede ver cómo el caso incluye consideraciones para revertir una situación de sometimiento que padecen los niños y niñas incluidos los migrantes. La Corte IDH le exigió al Estado que garantice el acceso a la educación primaria y gratuita a todos los niños, independientemente de su ascendencia u origen. Estas medidas se convierten en medidas transformativas, que intentan quebrar la situación de desigualdad que atraviesan estos niños en miras a obtener una igualdad real de oportunidades. Por otro lado, la Corte IDH habla de cómo la falta de acceso a la nacionalidad o el desconocimiento de la igualdad entre nacionales y extranjeros en la legislación interna aunque las Constituciones consagren iguales derechos para nacionales y extranjeros —-sin obligación de nacionalización_-, afecta otros derechos que hacen a lo que la Corte IDH llama "condiciones de existencia digna” (Villagrán Morales).

Además, en muchos casos, las personas por ser extranjeras (o por no tener determinada nacionalidad), especialmente los migrantes, padecen "discriminaciones múltiples”, esto implica que no solo son discriminadas por ser extranjeras sino que además pertenecen a otros grupos desaventajados. En lo que respecta a nacionalidad, un caso paradigmático - aunque por ahora excepcional en la jurisprudencia interna- es el caso "Reyes Aguilera” resuelto por la Corte Suprema de Justicia argentina. En el caso se trata de una niña de nacionalidad boliviana con una discapacidad que le impedía la movilidad de sus miembros, comunicarse verbalmente y alimentarse por cuenta propia. Se solicita una pensión a su favor que le es denegada por la Administración porque el art. 1.e del Decreto n. 432/1997 establecía respecto de las personas extranjeras un plazo mínimo de residencia de 20 años, para el otorgamiento de una pensión "por invalidez". Dicho decreto tenía como objetivo "cubrir contingencias sociales absolutamente extremas, vale decir, situaciones que ponen en juego, de manera palpable y potente, la subsistencia misma de la persona... carente 
de recursos o amparo", situación en la que se encontraba la niña. Caracterizamos a este caso como paradigmático porque pone en evidencia la fuerte discriminación que padecen los extranjeros en situación de vulnerabilidad, en este caso una niña: proveniente de un país limítrofe (Bolivia), en situación de discapacidad severa y de pobreza. Si bien la Corte Argentina declaró que el recaudo de residencia era inconstitucional, cuando se encontraren reunidos los otros requisitos (invalidez y pobreza), los votos de los magistrados tuvieron un eje argumentativo vinculado con cada uno de estos supuestos de discriminación. Los jueces Fayt y Zaffaroni argumentaron que el requisito de 20 años de residencia implica un desconocimiento de la seguridad social, derecho que se encuentra íntimamente vinculado con la vida, "cuya garantía, mediante acciones positivas, resulta una obligación impostergable de las autoridades públicas" (cons. 7), más aun cuando se trata de la protección de los “más débiles". En el caso, aun cuando los jueces no lo mencionan expresamente, la debilidad consistía en ser una menor discapacitada y pobre (art. 75, inc. 23). Por otro lado, los jueces Petracchi y Argibay se apoyaron en el argumento de la igualdad. Sostuvieron la presunción de inconstitucionalidad de toda categoría que distingue sobre la base de criterios prohibidos, categoría sospechosa (art. $1 .^{\circ}$ de la Convención Americana de Derechos Humanos): establecieron que la norma solo sería válida si supera un test de escrutinio intenso, recayendo en cabeza del Estado la carga de justificar que no existían alternativas menos lesivas para los fines sustanciales que se intentaban alcanzar mediante la norma impugnada (con cita de Gottschau, cons. 11). En el caso, los argumentos brindados por el Estado Nacional "resultan ineficaces para revertir la presunción de inconstitucionalidad de la norma en cuestión” (cons. 12). El juez Maqueda sostuvo si bien la diferencia de trato entre nacionales y extranjeros no está prohibida, esto no releva al legislador de establecer requisitos razonables, es decir que no impliquen desconocer el derecho. En el caso,

es la desproporcionalidad de la extensión del plazo lo que es inconstitucional. La irrazonabilidad del plazo consignado importa en los hechos que la aplicación de tal norma se traduzca en una discriminación indirecta ya que por las consecuencias que irroga, en la práctica, el beneficio de la pensión por invalidez estaría vedado para los extranjeros con residencia acreditada en el territorio argentino. ${ }^{48}$

Tenemos entonces que la nacionalidad es un criterio de clasificación prohibido y que implica la aplicación de un examen estricto de igualdad. La jurisprudencia analizada nos permite observar que ha existido un cambio en el paradigma en el concepto de igualdad, en el que se entendía la nacionalidad no solo como la categoría que distingue entre nacionales y extranjeros sino también como una categoría que impide el acceso a determinados derechos fundamentales de las personas, aun cuando las 
mismas se encuentren viviendo en el país. Vimos como este cambio de paradigma ha permitido reconocer derechos principalmente a aquellas personas que no solo padecen una discriminación por la nacionalidad sino también, principalmente, a los migrantes y otros grupos que padecen una situación de desventaja estructural.

\subsection{ETNIA}

En América Latina y el Caribe conviven diferentes grupos étnicos, siendo, los indígenas o pueblos originarios, ${ }^{49}$ la población afrodescendiente y la población asiática "objeto" de discriminación en el continente.

Los afrodescendientes constituyen una fracción muy significativa de la población regional, pues representan entre el $20 \%$ o el 30\%. Sin embargo, la identificación de un afrodescendiente no está exenta de problemas. Al respecto sostuvo la Corte Constitucional Colombiana que "al momento de determinar la inclusión de un sujeto en una de las comunidades étnicas... prima la conciencia de la pertenencia a tal comunidad, sus manifestaciones culturales, su historia y su proyección presente. Esto implica que, si bien se puede seguir teniendo en cuenta el aspecto racial para determinar la pertenencia de una persona a un grupo étnico específico, tal factor no es definitivo ni prioritario. Hablar de protección de la comunidad negra, de manera exclusiva y excluyente por su color de piel es un acto discriminatorio". De esta manera, el "aspecto racial" no debe ser un factor determinante para reconocer al sujeto como perteneciente a una determinada comunidad étnica.

Ahora bien, la totalidad o una gran cantidad de esta población se encuentran en una situación de pobreza mayor que la que padecen otros grupos. ${ }^{50}$ Básicamente las causas de esta desigualdad se originan en que históricamente los afrodescendientes en América Latina y el Caribe han estado segregados, discriminación que se identifica con el hecho de la esclavitud padecida por sus ascendientes y en el mantenimiento de ciertas prácticas sociales que les impiden acceder en igualdad de condiciones a ciertos derechos. ${ }^{51}$ A esto se suma el hecho de que existen escasos datos respecto de esta población, esto implica su invisibilización y la consiguiente imposibilidad de adoptar políticas públicas reparadoras o transformativas. Al respecto se ha dicho que "los censos y encuestas utilizados en América Latina no siempre incorporan la pregunta relativa a la identificación étnico-racial... Recientemente, en varios censos y encuestas de los países de América Latina se ha hecho operativa la identificación de los grupos étnicos a través de los criterios de la lengua materna y de la autopertenencia o autoidentificación”. Asimismo, "a estos aspectos hay que añadir las escasas posibilidades de participación en el sistema político. En efecto, en muy pocas excepciones, las poblaciones afroecuatorianas cuentan con representantes en los órganos de poder estatal y en los gobiernos seccionales como municipios y concejos provinciales". ${ }^{52}$ Como consecuencia, la condición de afrodescendiente afecta el goce de otros derechos. Así, se ha dicho que "la situación de marginación social de la que ha 
sido víctima la población negra... ha repercutido negativamente en el acceso a las oportunidades de desarrollo económico, social y cultural”. ${ }^{53}$ De esta manera, los afrodescendientes padecen de una desigualdad estructural que no proviene solo de la falta de acceso a ciertos bienes que resultan necesarios para poder salir de la situación de desventaja en la que se encuentran sino que además padecen una falta de reconocimiento de su subjetividad como colectivo. En este último sentido, con la ola de reformas constitucionales que se da a partir de los años 1980, en muchos de los países latinoamericanos se incorporan a las constituciones disposiciones de reconocimiento de derechos de estas comunidades, y se reconocen como países multilingües y multiculturales, ${ }^{54}$ como asimismo se establece la necesidad de realizar acciones afirmativas para lograr erradicar la desigualdad que padecen los miembros de estas comunidades (en el acceso a la salud, la educación, la seguridad social, la participación política, entre otros). En este sentido, se pronunció la Corte Constitucional Colombiana en relación con las acciones afirmativas y las comunidades afrodescendientes en la Sentencia T-1090/05 como forma de "asegurar el adecuado desenvolvimiento y protección de ciertos grupos raciales o de personas pertenecientes a estos grupos, con el fin de garantizar en condiciones de igualdad el pleno disfrute por dichas personas de los derechos humanos y de las libertades fundamentales". Asimismo, diagnosticó que "existe consenso en que la formación escolar general no es un bien distribuido en forma equitativa en América Latina y, en el caso de los afrodescendientes en muchos de los países de la región, les lleva a enfrentar dificultades para acumular capital humano, lo que se refleja en su inserción laboral y en sus ingresos. La discriminación presente en el ingreso a la formación escolar general o en el acceso a la calidad de esta formación aumentará cuando las personas víctimas de la discriminación entren a competir en el empleo y la ocupación." 55 Así, pronosticó como acción afirmativa que "la formación escolar es el punto de partida para acceder a más educación y mejores empleos”. 56

Sin embargo, la aplicación de estas medidas afirmativas no está exenta de problemas. Así pues, en el caso T-375/06 la Corte Constitucional Colombiana se expidió respecto de la necesidad de realizar acciones afirmativas en lo que respecta al desarrollo educativo de los miembros de las comunidades afrocolombianas. Nellys Mejía Moreno se presentó ante la Universidad del Magdalena para ser admitida en la Facultad de Medicina como afrocolombiana, calidad que había sido reconocida por la Organización de Comunidades Afrocolombianas de la Zona Bananera. Dicha Universidad tiene un acuerdo con las comunidades afrocolombianas (n. 0024-01), conforme el cual el establecimiento debe admitir a un estudiante afro en cada facultad, siempre que el mismo alcance un determinado puntaje. ${ }^{57}$ En este sentido, esta medida constituía una acción positiva respecto de la comunidad afro. Mejía Moreno había rendido el examen de admisión y alcanzado un puntaje mayor que el mínimo exigido quedando en el primer puesto en la lista de aspirantes, sin embargo, no fue 
admitida. En consecuencia, Mejía Moreno inició una acción judicial porque encontraba la no-admisión contraria a su derecho a la igualdad. La Universidad demandada alegó como principal punto de su argumento que "durante la entrevista se encontró que la certificación de la pertenencia a la comunidad afrodescendiente no coincidía con la realidad, pues la fisonomía de la actora no corresponde a la de negritudes. Indica que, debido al mestizaje, la gran mayoría de 'costeños' son en alguna medida afrodescendientes. No obstante, es claro que existen personas que no han tenido mayor mestizaje que sufren tratos inequitativos y pobreza. Este grupo de personas ha conservado sus tradiciones e identidad y merece especial trato". Asimismo, adujo que había sido admitida otra persona afro en la universidad (la que obtuvo el puesto posterior al de Mejía Moreno).

$\mathrm{Al}$ respecto, la Corte sostuvo que las acciones positivas en materia educativa no pueden ser obstaculizadas por las autoridades encargadas de desarrollar los programas. Pese a que Mejía Moreno reunía todos los requisitos, como su fisonomía física no encajaba con los rasgos típicos (principalmente, color de piel) no fue admitida en la Universidad. Sostuvo la Corte que esto implica un trato discriminatorio contrario al art. 13 de la Constitución Colombiana y ordenó que se admita a Mejía Moreno en la Facultad de Medicina. La inconstitucionalidad de la no-admisión de Mejía Moreno no desaparece por el hecho de que la Universidad haya aceptado a otra persona de la comunidad afro, pues esta admisión se realiza en otro programa de formación profesional (ingeniería pesquera).

La misma postura es seguida por la Corte Colombiana en el caso de representantes de las comunidades afrodescendientes en las Juntas Educativas. La Sentencia T-422/96 se origina porque el Departamento Administrativo de Servicio Educativo Distrital _-DASED_ se había abstenido de designar en la Junta Distrital de Educación, el representante de las "comunidades negras". ${ }^{8}$ Alegaba que en la zona de Santa Marta no existían poblaciones de tales características. La Corte Constitucional Colombiana ordenó la designación de un representante de comunidades afro al interpretar que

al regular la composición y fines de las juntas distritales de educación, [se] introdujo una medida de igualdad promocional general, dirigida a favorecer a la comunidad negra... Una forma de asegurar que hacía el futuro la educación no sea un campo de discriminación, puede ser, como lo intenta la ley, que representantes de la población negra tomen asiento en la juntas distritales de educación, junto a los representantes de otros grupos y sectores de la sociedad y del Estado.

Los problemas de discriminación que debe enfrentar la población afrodescendiente también se verifican en Brasil. En este sentido, "los esfuerzos por combatir el 
racismo en Brasil han venido incursionando de manera creciente en el terreno del derecho. Primero se buscó establecer una legislación rigurosa que garantizara la severa punición de los actos racistas, y fue paulatinamente especificada y ampliada". ${ }^{59}$ Dicha legislación fue la base para el dictado de sentencias que condenan los actos racistas. Sin embargo, estas medidas resultan insuficientes para lograr la igualdad de condiciones de la población afrodescendientes. Por ello se adoptan políticas compensatorias, tanto en el ámbito estatal como municipal, que implican el acceso preferencial de afrodescendientes a determinadas posiciones (por ejemplo, ley de cuotas en las universidades). Estas acciones constituyen "medidas jurídicas preventivas y transformadoras, destinadas, por ejemplo, a garantizar un ejercicio igualitario de los derechos a la educación, al trabajo y a la libre búsqueda de formas de vida culturales". 60 Sin embargo, estas medidas han sido cuestionadas alegando que implican discriminación pues se fundan en criterios prohibidos de discriminación. En este sentido, en la Acción Directa de Inconstitucionalidad 3.330-1 del Distrito Federal, el Juez (relator) Carlos Ayres Britto se manifestó respecto de la constitucionalidad de Ley n. 11.096, de 13 de enero de 2005, por la cual se instituía el Programa Universidad para Todos (Prouni), siendo el objetivo principal el financiamiento del estudio de los afrodescendientes y los indígenas en las universidades privadas. ${ }^{61} \mathrm{La}$ Confederação Nacional dos Estabelecimentos de Ensino (Confenen) cuestionaba la constitucionalidad de la medida pues resultaría contraria al, entre otros, principio de igualdad. El voto toma en cuenta dos cuestiones principales. Por un lado, remarca la importancia que tiene la educación para el ejercicio de la ciudadanía y la calificación para el trabajo - Como un derecho social (art. 6. ${ }^{\circ} \mathrm{CF}$ brasileña). En este sentido, el Estado debe garantizar el acceso a los niveles más elevados de enseñanza (art. 205, V de la CF brasileña), debiendo ser, a su vez, una de sus políticas públicas de primerísima prioridad. Afirma que la normativa impugnada tiene como objetivo: (a) el fácil acceso de estudiantes en desventaja económica a la educación universitaria; (b) el desempeño de las entidades de asistencia social en la educación superior. Por otro lado, en su voto el juez resalta las implicancias del derecho a la igualdad y la no-discriminación, como asimismo el efecto y la necesidad de establecer acciones positiva: sostuvo que la distinción se funda en factores históricos y culturales, ya que estos sectores brasileños (negros e indios) han sido históricamente desfavorecidos, culturalmente perseguidos e incluso asesinados. No es coincidencia que se encuentren en los sectores patrimoniales más bajos de la pirámide social (cons. 40). Por esto, la distinción a favor de los estudiantes que asistieron a las escuelas públicas y los graduados de las escuelas privadas que han obtenido una beca completa no ofende la Constitución, porque es un desequilibrio que implica una compensación de la previa inferioridad de hecho. Así, la deseada igualdad entre las partes se obtiene por el choque de las desigualdades (una de hecho y otra jurídica, esta última para contrabalancear el peso de la primera) (cons. 41). 
Vemos entonces que si bien existen avances en lo que respecta al reconocimiento de la igualdad de la población afrodescendiente, dicho grupo sigue padeciendo de una situación de opresión intersectorial, existiendo una estrecha relación entre pobreza y etnia. Esta situación impone la necesidad de adoptar políticas públicas no solo reparadoras sino principalmente transformativas que impliquen avances importantes en el goce de la igualdad real de condiciones.

Se pueden identificar otros grupos residentes en la región, como, por ejemplo, la población asiática (chinos, taiwaneses, coreanos, etc.), que también son "objeto" de discriminación. En este sentido, los informes sobre la situación actual de esta población en América Latina y el Caribe no son abundantes, como tampoco lo son las sentencias que se refieran a la desigualdad que padecen. Al respecto, la Sala Constitucional de la Corte Suprema de Justicia de Costa Rica en la sentencia n. 14.852, del 6 de octubre del 2006, condena a Ferreterías El Mar Sociedad Anónima por el trato discriminatorio impartido a Tin Wong Yin. Wong acudió al local de Ferretería, a fin de adquirir algunos artículos, ya en el local fue interpelado por un empleado para que se retirara del lugar alegando que "aquí no queremos el ingreso de orientales”. Wong solicitó que le explicaran las razones que fundamentan ese trato. El empleado simplemente respondió llamando a un oficial de seguridad quién obligó a Wong _ arma en mano-_ a abandonar el local. La Sala Constitucional sostuvo que la discriminación contra Wong se fundó en razones étnicas, lo que implica un examen de igualdad riguroso que no fue desvirtuado por la empresa. Por su parte, la Corte Suprema de Justicia argentina se pronunció en el caso "Ani, I-Hsing s/ carta de ciudadanía” (23/06/2009). Estableció que no es un requisito la residencia legal para obtener la ciudadanía argentina, ya que la ley solo habla de residencia sin hacer distinciones. En el caso, se trataba de un ciudadano de nacionalidad china que vivía en el país desde hacía varios años y que había solicitado la carta de ciudadanía en varias ocasiones, siendo esta negada por la dependencia estatal de migraciones que alega que su residencia no contaba porque habitó en el país en situación ilegal.

Las sentencias analizadas muestran claramente que existe un compromiso por parte de los gobiernos latinoamericanos a reconocer derechos a grupos que han sido históricamente discriminados por su etnia. Esto se ha traducido en la implementación de acciones positivas o de discriminación inversa, que si bien por el momento parecen ser insuficientes, pues las mismas son parciales, ${ }^{62}$ el desafío consiste en lograr una implementación progresiva y más amplia de las mismas. Siempre teniendo presente que la existencia de estos grupos "plantea el reto de construir una sociedad respetuosa de las diferencias entre personas y grupos distintos entre s'”. 63

\subsection{EDAD}

Es común ver que el legislador utilice la edad como criterio para establecer diferencias de trato, por ejemplo, para obtener la licencia de conducir automóviles, para 
votar, para ejercer cargos electivos. De esta manera, no surge a primera vista que la edad sea un criterio que nos haga sospechar de la clasificación que arroja la norma. Así, varias Cortes constitucionales han confirmado la constitucionalidad de normas que usan como criterio válido de selección la edad. En este sentido, alguna jurisprudencia interpreta que la edad no resulta por sí misma un criterio sospechoso, pero puede devenir en discriminatoria por los efectos que la clasificación produce en el ejercicio de un derecho. Así la Corte Constitucional Colombiana ha dicho que "[...] no todas las diferenciaciones por razón de la edad deben ser tratadas de la misma manera, ya que mientras no parece potencialmente discriminatorio que la ley exija edades mínimas para ciertos efectos"; por el contrario "resulta mucho más problemático que la ley establezca límites máximos a partir de los cuáles [sic] a una persona se le prohíbe realizar determinada actividad".

A su vez, la edad se torna relevante para identificar a grupos desaventajados: niños y niñas, por un lado, y personas de edad avanzada, por el otro. Es cierto que la situación de vulnerabilidad de estas personas es aún peor si además se encuentran en situación de pobreza, de discapacidad, pertenecen a una etnia discriminada, son mujeres o niñas. En este sentido, debe resaltarse que tantos niños y niñas como personas ancianas fueron identificados por el constituyente argentino como colectivos dignos de una mayor protección, en clave de medidas de acción positiva para el ejercicio real de derechos en igualdad de condiciones (art. 75, inc. 23, de la Constitución argentina). ${ }^{64}$

La Corte Suprema argentina decidió casos en los que se atacaban normas en las que la edad era utilizada como un límite máximo para continuar en un trabajo. Estos casos fueron resueltos aplicando el principio de no-discriminación bajo utilización de un examen de igualdad entre leve e intermedio. En el caso "Domínguez, Alberto Roberto c/ U.N.R. s/ amparo” aplicó un examen de mera racionalidad y confirmó así la constitucionalidad de una norma que impone el cese de los docentes universitarios al cumplir 65 años de edad. Las razones se deben a que alcanza a "la generalidad unánime del claustro, sin atender a diferencias personales de especie alguna" y "no obedece a ánimo persecutorio de ninguna índole sino que está concebida al margen de su eventual grado de acierto, que no cabe aquí analizar, únicamente como una pauta no irrazonable de organización de la carrera docente universitaria". 65 Sin perjuicio de lo cual, en el caso "Franco", bajo aplicación de un examen de igualdad con tendencia a un nivel de exigencia intermedio, declaró la inconstitucionalidad de una norma provincial que ponía un límite de 75 años al ejercicio de la Escribanía en el territorio de la Provincia de Buenos Aires. 66

También, la Corte Constitucional Colombiana presenta líneas jurisprudenciales en las que la edad fue considerada como un criterio que requiere entre un examen leve a intermedio. Por ejemplo, ha señalado que la protección del libre desarrollo de la personalidad de una persona depende de su grado de autonomía, lo cual justificaría "ciertas injerencias" de los padres y de las autoridades en los niños, que serían 
inadmisibles en los adultos. ${ }^{67}$ Incluso respecto de los adultos, ha considerado que la ley puede tomar en cuenta la edad como requisito para acceder a ciertos cargos o bienes y, por ejemplo, declaró la exequibilidad de la norma que establece que para ser notario la persona debe tener al menos 30 años, pues: "El señalamiento de una edad mínima para desempeñar cierta actividad no implica desconocimiento del derecho al ejercicio de la función pública y menos todavía vulneración del derecho al trabajo. El Estado tiene que buscar por distintos medios - uno de los cuales es precisamente este- la aptitud y madurez de las personas para asumir ciertas responsabilidades, en interés de la comunidad. Y no es que la edad per se otorgue una plena seguridad al respecto sino que ella, unida a otros requisitos - como el nivel de preparación académica y la experiencia adquirida en el campo de la profesión correspondiente- otorga un mayor grado de confiabilidad en el titular del empleo en cuestión". 68 Asimismo consideró que no era discriminatoria una convocatoria de Colciencias para obtener una beca para hacer estudios de posgrado en el exterior, los candidatos no debían ser mayores de 38 años. Sin embargo, la Sentencia C-071 de 1993 (MP. Alejandro Martínez Caballero) declaró la inconstitucionalidad de la norma que establecía que para ingresar a la carrera diplomática y consular era necesario tener menos de 30 años, pues:

En efecto, lo único que poseen las personas menores de treinta (30) años de edad respecto de las demás es juventud y mayor esperanza de vida, que para el efecto es irrelevante y no justifica la discriminación. [...] Además una de las categorías de la población colombiana que amerita un particular reconocimiento laboral del Estado es la franja comprendida entre los años de juventud y la tercera edad, normalmente denominada "edad adulta", para que se garantice su intervención en la vida económica, política y cultural de la nación. Incluso entre los 30 y los 64 años de edad las mujeres y los hombres atraviesan su época laboral más fecunda, dada su preparación académica y la experiencia que se ha adquirido a través de los años.

Ahora bien, como advertimos sobre el comienzo, la desigualdad cuando se refiere a personas de edad avanzada requiere de especial consideración porque combinada con otras causales de opresión (situación de discapacidad, pobreza, género, etnia) constituye un grupo vulnerable. De acuerdo con un estudio reciente de la CEPAL: ${ }^{6}$ "El paulatino pero inexorable envejecimiento de la población de América Latina y el Caribe presenta dos características que preocupan: un ritmo más rápido que el registrado históricamente en los países desarrollados y un contexto caracterizado por una persistente desigualdad, un débil desarrollo institucional, sistemas de protección social de baja cobertura y calidad y una institución familiar muy exigida en materia de seguridad y protección. [...] Los derechos de las personas mayores han ido cobrando 
importancia para los gobiernos y desde hace algunos años esta preocupación se ha traducido en la creación de marcos legales de protección”. Sin embargo, ese mismo estudio alerta que "existe una amplia brecha entre la situación de jure y de facto, porque persisten insuficiencias en el ejercicio efectivo de estos derechos y, hoy en día, una parte importante de la población adulta mayor carece de acceso a prestaciones de seguridad social, servicios de salud o servicios básicos”. En la mayoría de los casos, esta "vulnerabilidad" no se basa simplemente en la edad de las personas sino "en una generalizada precariedad de los dispositivos de protección establecidos por los Estados. En otros casos, son expresión de una abierta desigualdad en función de los ingresos o bien de una escasa consideración de las necesidades de este grupo social como un asunto de política pública, producto de la arraigada concepción de que los problemas de la vejez son de orden privado y no objeto de solidaridad colectiva”. Esto ha llevado a que los Estados implementen diversas medidas de acción positiva pero, como advierte el estudio, éstas son aún insuficientes debido a la situación de partida de desventaja de varias personas de edad avanzada.

Así, la sentencia dictada en mayo del 2009 por la Corte Constitucional de Ecuador habla de una medida de acción positiva implementada a favor de las personas ancianas de menores ingresos. ${ }^{70}$ En el caso trató la acción de inconstitucionalidad iniciada por un abogado en libre ejercicio profesional, quien solicitó a la Corte Constitucional, que se declare la inconstitucionalidad de una norma referida al personal de la Administración Pública que establece que los jubilados en general y los que reciban pensiones de retiro, solo podrán reingresar al sector público siempre que sus pensiones mensuales no superen los quinientos dólares de los Estados Unidos de América. La Corte entendió que la norma no implicaba una discriminación arbitraria, ya que la cuestión está en establecer si aquella diferenciación hecha por el Legislador es o no legítima. Así entiende que la diferenciación se traduce en igualdad de oportunidades a través de acciones positivas, las cuales son: permitir el reingreso al sector público de todos aquellos jubilados que perciban una renta mensual baja; y permitir el ingreso al sector público de todas aquellas personas que lo desean y aún no lo han hecho, por ser desempleadas. Por ello, considera que se está frente a un caso legítimo de discriminación positiva, que establece ventajas para un grupo desventajados (jubilados y pensionistas del sector público que menos renta perciben por concepto de jubilación) para alcanzar igualdad material. Por lo tanto, vemos que la Corte con acierto no aplica un examen de escrutinio estricto cuando la edad es utilizada para mejorar la situación del grupo que se encuentra en peores condiciones de ejercicio de derechos.

Por su parte, la Corte de Suprema de Justicia argentina resolvió tres casos, ${ }^{71}$ en los que ordenó a la obra social de los jubilados (PAMI) la provisión gratuita de medicamentos para sus afiliados. En todos ellos estaba probado que los asociados no podían afrontar el costo de los fármacos e insumos y que sus enfermedades se encontraban en estado avanzado, respectivamente. En estos casos las sentencias se convierten en medidas de acción positiva para lograr igualdad real en el acceso a los medicamentos. 
Ahora bien si la vejez es utilizada para empeorar la situación de los que están en peores condiciones, entonces, corresponde realizar un examen más cuidadoso de la clasificación. Dos casos de la Corte Constitucional Colombiana se mueven en este sentido, es decir, cuando el tránsito hacia la vejez puede ser tomado como una imagen estereotipada de la persona que lleva a una discriminación arbitraria. En estos casos, se parece hablar de remover obstáculos normativos o interpretativos que tomen a la vejez como causal de discriminación. La sentencia SU-224 de 1998 (MP Hernando Herrera Vergara) se trataba de la petición de una madre comunitaria ${ }^{72}$ contra la decisión de la Administración que había decidido cerrar su hogar comunitario; la mujer se consideraba discriminada pues entendía que el cierre se debía entre otras cosas a que ella había superado los 55 años. Esta es la edad máxima prevista por un acuerdo de esa entidad para poder ser madre comunitaria. La sentencia no amparó a la peticionaria, ya que interpretó que no resultaba claro que la edad hubiera sido la verdadera razón del cierre del hogar comunitario. No obstante, la Corte advirtió que "si la única circunstancia para retirar a la demandante era la de haber llegado a la edad máxima de 55 años, se hubiese podido configurar la violación del derecho a la igualdad, en el evento de que ello estuviese suficientemente acreditado por los medios legales pertinentes”. Este último criterio fue utilizado para justificar la sentencia T-394/99 (MP Martha Victoria Sáchica de Moncaleano).

El otro grupo de personas que históricamente ha sufrido estados de sometimiento por su edad es el conformado por niños y niñas. Nuevamente la situación de desigualdad afecta con mayor intensidad y especialmente a niños y niñas en estado de indigencia o pobreza y/o en situación de discapacidad y/o afrodescendientes y/o de comunidades indígenas y que habitan zonas rurales. Varios Estados de América Latina y el Caribe han ratificado la Convención Internacional de los Derechos del Niño y cuentan en sus Constituciones y legislación con normas que especialmente hablan a favor de los derechos de niños y niñas, y algunos Estados han implementado medidas de acción positiva para la niñez (Asignación Familiar por Hijo, plan Bolsa, entre otras). Sin embargo, estas acciones positivas son aún insuficientes para lograr igualdad real de condiciones. En este sentido, sigue retumbando en el trasfondo de la región las palabras pronunciadas en el caso paradigmático resuelto por la Corte IDH "Villagrán Morales" sobre niños de la calle en el que sostuvo que los derechos (en el caso específico, el derecho a la vida y a la integridad física) se violan no solo por omisión estatal sino también por incumplimiento de obligaciones positivas del Estado para generar condiciones de existencia digna, ya sea de niños, y luego agregó en otros casos, de personas detenidas, de personas internadas, de comunidades indígenas. ${ }^{73}$ Respecto de cómo esa falta o insuficiencia de acciones positivas implica desigualdad para los "niños de la calle” agregó:

En los últimos años, se han deteriorado notoriamente las condiciones de vida de amplios segmentos de la población de los Estados parte de la 
Convención Americana, y una interpretación del derecho a la vida no puede hacer abstracción de esta realidad... (párr. $6 .^{\circ}$ ). Creemos que el proyecto de vida es consustancial del derecho a la existencia, y requiere para su desarrollo condiciones de vida digna, de seguridad e integridad de la persona humana... (párr. $8 .^{\circ}$ ) Una persona que en su infancia vive, como en tantos países de América Latina, en la humillación de la miseria, sin la menor condición siquiera de crear un proyecto de vida, experimenta un estado de padecimiento equivalente a una muerte espiritual; la muerte física que a ésta sigue, en tales circunstancias, es la culminación de la destrucción total del ser humano. Estos agravios hacen víctimas no solo a quienes los sufren directamente, en su espíritu y en su cuerpo; se proyectan dolorosamente en sus seres queridos, en particular en sus madres, que comúnmente también padecen el estado de abandono (párr. $9 .^{\circ}$ ). ${ }^{74}$

En este sentido, en la Sentencia T-447/05, la Corte Constitucional Colombiana se pronunció sobre la edad como criterio de clasificación en relación con el derecho a la permanencia en el sistema educativo aplicando un examen de igualdad bien intensivo, en tanto se excluía a niños pobres de lo que se garantizaba a quienes se encuentran en mejores condiciones económicas y sociales. A su vez obligó al Estado a implementar medidas de acción positiva para mejorar el acceso de los niños y niñas — de zonas rurales y pobres - a la educación secundaria. Se trata en el caso de unos niños que no pueden asistir a la educación básica formal, por cuanto el único colegio de bachillerato que existe en la región y el más cercano a ellos se encuentra a más de cuatro horas de camino. Sus padres son trabajadores rurales y la familia vive en condiciones económicas de pobreza. Los padres iniciaron acción de tutela contra el Estado para lograr que sus hijos fueran admitidos en el Sistema de Aprendizaje Tutorial (SAT), ya que la Secretaría de Educación Departamental denegó la petición de inscribirlos en el SAT porque una norma dispone que ese sistema solo está disponible para aquellos educandos que aporten como pruebas una certificación de haber aprobado quinto de primaria y un registro civil en el que se compruebe que cumplieron 15 años de edad. Los niños se encontraban terminando su educación básica primaria con edades que oscilaban entre los 10 y los 12 años de edad. En la sentencia T-612/06 afirma que

por mandato constitucional el Estado debe de ofrecer y garantizar el acceso y permanencia en el sistema de educativo, pero, además, jurisprudencialmente, se ha señalado que no pueden existir limitaciones discriminatorias que imposibiliten a las personas interesadas en formarse académicamente el acceso al conocimiento. Las únicas limitaciones aceptables serán aquellas que por razones de técnica académica y metodología del aprendizaje influyan de manera positiva, para que los educandos aprovechen y se beneficien al 
máximo del proceso educativo. En esta medida, la edad, como factor de clasificación de los sujetos activos en el proceso educativo, puede tomarse como criterio de categorización del alumno en alguno de los niveles del sistema nacional de educación, ya sea bajo el esquema de una educación formal o no, pero no podrá servir para excluir o no permitir el acceso del estudiante al sistema educativo. Si ello ocurre se impone un trato discriminatorio, violando en consecuencia el derecho a la igualdad. Circunstancia que se presenta en este caso, pues se imposibilita a los menores de 15 años, que han terminado su educación primaria o que están próximos a ello, continuar su proceso formativo.

La Corte concluye que no puede aceptarse el argumento de la edad para excluirlos basados en el grado de madurez y responsabilidad de los estudiantes, características estas que se adquirirían, según la norma atacada, a partir de los 15 años de edad. Para la Corte, el solo deseo de permanencia en el sistema educativo expuesto por los accionantes debe ser tenido en cuenta como criterio de madurez para admitir a los niños al programa. Como remedios ordena que la Secretaría de Educación deberá implementar procesos educativos, de educación básica secundaria, continuos y completos que consideren las condiciones geográficas en que se localiza la potencial población estudiantil, así como sus condiciones económicas y sociales. Pero mientras esto no ocurra los niños y niñas de la región deberán ser admitidos a la única alternativa viable para continuar con su proceso educativo, hasta la fecha.

La situación de desigualdad basada en la niñez debe ser una circunstancia de especial consideración de los jueces en los casos que se reclame por el derecho a la salud de niños y niñas, según la Corte Suprema de Justicia argentina. Esa Corte decidió varios casos a favor del derecho a la salud de niños y niñas que no accedían a los tratamientos por su situación económica o social y, además, la situación se agravaba porque los niños se encontraban en estado de discapacidad. En la mayor parte de los casos el estado de salud de los niños era grave y la prestación requerida era de carácter urgente. Todos estos casos fueron resueltos a favor de los derechos de los niños. Para ello se realizaron consideraciones de igualdad; incluso la Corte Suprema argentina alertó a los jueces inferiores que cuando está en juego el interés superior de un niño, los jueces deben dejar de lado los formalismos y buscar una solución urgente al problema. ${ }^{75}$ Sin embargo, la mayor parte de estos casos habla de soluciones puntuales. Así, la Corte no realiza consideraciones referidas a que la reiteración de estos reclamos devela insuficiencias estructurales del sistema de salud que implican desigualdad, entre otros, para niños y niñas.

\subsection{Discapacidad}

De acuerdo con informes recientes, más de mil millones de personas viven en todo el mundo con alguna forma de discapacidad. Respecto de esas personas, alrededor 
de 200 millones experimentan dificultades considerables en su funcionamiento. En todo el mundo, las personas con discapacidad "tienen peores resultados sanitarios, peores resultados académicos, una menor participación económica y unas tasas de pobreza más altas que las personas sin discapacidad”. ${ }^{76}$ Las razones de esta desigualdad son conocidas: "los obstáculos que entorpecen el acceso de las personas con discapacidad a servicios que muchos de nosotros consideramos obvios, en particular la salud, la educación, el empleo, el transporte, o la información. Esas dificultades se exacerban en las comunidades menos favorecidas". ${ }^{77}$ Ante esta situación, la obligación en términos igualitarios es "emancipar a las personas que viven con alguna discapacidad y suprimir los obstáculos que les impiden participar en las comunidades, recibir una educación de calidad, encontrar un trabajo digno y lograr que sus voces sean escuchadas". ${ }^{78} \mathrm{Al}$ respecto, no se trata solo de aprobar medidas que remuevan obstáculos y medidas de acción positivas, se requiere también que éstas sean implementadas y cumplidas en forma continua y sistemática. Por ejemplo, según el documento citado de los informes de los países que tienen leyes sobre accesibilidad, aun en el caso de que éstas tengan una antigüedad de 20-40 años, confirman un bajo nivel de cumplimiento. Otro tanto podría predicarse de las leyes sobre protección integral de las personas con discapacidad tendentes a lograr igualdad real en el ejercicio del derecho a la salud y a la educación entre otros. La jurisprudencia de los tribunales y cortes superiores de la América Latina y el Caribe da cuenta de estos incumplimientos ${ }^{79}$ y de las formas diversas de discriminación que padecen, "que van desde la discriminación directa, como, por ejemplo, la negativa a conceder oportunidades educativas, a formas más 'sutiles' de discriminación, como, por ejemplo, la segregación y el aislamiento conseguidos mediante la imposición de impedimentos físicos y sociales". ${ }^{80} \mathrm{Al}$ respecto es ilustrativa la jurisprudencia de la Corte Constitucional Colombiana cuando realiza una especie de reconstrucción retrospectiva de sus sentencias sobre las personas con discapacidad y establece que: "[...] ha reconocido la situación de marginación social en que ha permanecido la población con discapacidad a lo largo de la historia ${ }^{81}$ y ha señalado que tal reconocimiento impone la toma de decisiones con el fin de remover los obstáculos que impiden su adecuada integración social en igualdad de condiciones reales y efectivas". ${ }^{82}$ En aras de lograr dicha igualdad, se hace necesario que el Estado tome medidas de diferenciación positiva en favor de las personas con discapacidad. De hecho, la jurisprudencia constitucional ha indicado que la omisión del trato especial a esta población puede constituir una medida discriminatoria "por cuanto la no aplicación de la diferenciación positiva en el caso de las personas discapacitadas permite que la condición natural de desigualdad y desprotección en que se encuentran se perpetúe, situación que les impide, entonces, participar e integrarse en las actividades sociales, para poder así ejercer sus derechos y responder por sus obligaciones". 83 
Una forma de aislamiento que padecen las personas con discapacidad está ocasionada por la imposibilidad de acceso a determinados lugares por las diversas y múltiples barreras arquitectónicas que presentan casi todas las ciudades de América Latina y el Caribe. Al respecto la Sala Constitucional de la Corte Suprema de Justicia de Costa Rica se pronunció en la sentencia del 27 de febrero del 2009 sobre un amparo interpuesto por una persona con discapacidad, Johnny Chinchilla Barboza, contra la Municipalidad del Paraíso por violar el derecho de igualdad e impedir la libertad de tránsito. Peticionaba la mejora de varios aspectos de la infraestructura urbana, ya que no existían rampas o pasos entre las aceras y las calles que permitan el acceso al comercio, tampoco existían semáforos audibles que permitieran un cruce seguro de las calles, para las personas con discapacidad visual, ni tampoco paradas de autobuses. Por su parte, la Municipalidad pidió que no se hiciera lugar al amparo ya que estas mejoras estaban incluidas como prioridades en una política de inversión y, además, que como los recursos económicos son escasos debían elegir prioridades. La Corte hace lugar al amparo porque entiende que: "El Estado y la sociedad en general, tiene la obligación de eliminar progresivamente las "barreras arquitectónicas" que les dificultan o impiden el libre tránsito a esta personas...", y "situaciones así no hacen más que negarle a esta población la posibilidad de insertarse en la sociedad de manera natural y realizar sus actividades de forma adecuada”. Agrega que, más allá de las promesas dadas por la Municipalidad, se están violando derechos fundamentales de las personas discapacitadas (en especial, el derecho a una vida independiente), por lo que se debe arribar a una solución en un plazo inmediato, ya que no pueden sujetarse el ejercicio de estos derechos a cuestiones presupuestarias. ${ }^{84}$

La Corte Constitucional Colombiana se pronunció sobre la cuestión de accesibilidad y movilidad en un caso en el que la Alcaldía Mayor de Bogotá se negaba a otorgar permiso de circulación en su vehículo particular a una persona que sufría de una cuadriplejía espástica (disminución de la fuerza muscular en las cuatro extremidades) durante las horas de restricción vehicular "pico y placa". Al respecto, concluyó que esta negativa configuraba una vulneración de sus derechos fundamentales a la igualdad, a la autonomía y a la libre circulación por omisión del deber de trato especial, con lo que ordenó la entrega del permiso. ${ }^{85}$ Asimismo, respecto del uso del servicio de transporte masivo Transmilenio, por una persona en situación de discapacidad que debía desplazarse en silla de ruedas, consideró que "la libertad de locomoción tiene una dimensión positiva y de orden prestacional cuya realización requiere, sobre todo en las grandes ciudades, un adecuado servicio público de transporte, que, además, debe estar regido por el principio de la progresividad, de manera que las prestaciones protegidas por un derecho requieren la adopción de políticas, planes y programas enderezados a avanzar gradualmente hacia el goce efectivo de los derechos por parte de todos los habitantes, y especialmente su disfrute por parte de ciertos grupos sociales, como la población con discapacidad". Así, "se 
desconoce la dimensión positiva de un derecho fundamental... cuando ni siquiera se cuenta con un plan que conduzca, gradual pero seria y sostenidamente a garantizarlo y protegerlo". En consecuencia, ordenó a Transmilenio S.A. diseñar un plan orientado a garantizar el acceso del actor al sistema de transporte público básico de Bogotá, "sin tener que soportar limitaciones que supongan cargas excesivas". Esta jurisprudencia pone de manifiesto que las medidas de acción tendentes a remover obstáculos para lograr accesibilidad también implican obligaciones para las empresas concesionarias de servicios públicos.

Las personas con discapacidad también tienen dificultades para el acceso al sistema educativo ya sea el general o responda a alguna modalidad especial. Al respecto surge que: "La formulación de políticas no siempre tiene en cuenta las necesidades de las personas con discapacidad, o bien no se hacen cumplir las políticas y normas existentes. Por ejemplo, en lo referente a las políticas educativas inclusivas, una revisión de 28 países que participaron en la Iniciativa Vía Rápida de Educación para Todos comprobó que 18 de ellos proporcionaban muy poca información sobre las estrategias propuestas para incluir a los niños con discapacidad en las escuelas, o no mencionaban en absoluto la discapacidad o la inclusión. Un déficit habitual en las políticas educativas es la falta de incentivos económicos y de otro tipo orientados a que los niños con discapacidad acudan a la escuela, así como la falta de servicios de apoyo y protección social para los niños con discapacidad y sus familias". ${ }^{86}$ La jurisprudencia de la región da cuenta de estos obstáculos convertidos en reclamos judiciales.

En la sentencia dictada el 23 de enero del 2009, la Sala Constitucional de la Corte Suprema de Justicia de Costa Rica se pronunció sobre un amparo interpuesto por una persona con discapacidad contra el Centro de Enseñanza Especial de Heredia y el Ministerio de Educación Pública, porque se lo inscribió pero en la lista de espera en el nivel de III Ciclo de los Centros de Enseñanza Especial (en el área de "Retraso Mental") debido a que el cupo de estudiantes previsto para ese curso estaba completo. La Corte hace lugar al amparo, y ordena la matriculación del amparado en ese centro educativo. ${ }^{87}$ Para ello, constató que en el caso había una clara violación al art. 14 de la Ley n. 7.600 que determina que el "Estado garantizará el acceso oportuno a la educación a las personas, independientemente de su discapacidad, desde la estimulación temprana hasta la educación superior. Esta disposición incluye tanto la educación pública como la privada en todas las modalidades del Sistema Educativo Nacional. Esta violación implicaba además el derecho a la educación del tutelado, pues le fue negada a este la matrícula en el Centro de Enseñanza Especial, a pesar de que dicho centro educativo es la institución que puede brindar el servicio educativo que mejor responde a las necesidades y características del amparado, tal y como afirma la Directora del mismo en su informe”.

Respecto al acceso a la educación universitaria, la Sala Constitucional de la Corte Suprema de Justicia de Costa Rica trató el amparo interpuesto por una persona "no 
oyente", que usaba audífonos y se comunicaba por medio del lenguaje de señas, contra la Universidad San Isidro Labrador por impedirle matricularse nuevamente por su falta de audición. ${ }^{88}$ La Universidad le había otorgado una beca completa a cambio de que el peticionante realice 40 horas de trabajo comunal por cuatrimestre. Debido a que no le asignaban tareas de acuerdos con sus capacidades, el recurrente solo pudo realizar 19 horas. Sobre la base de la falta de horas trabajadas, la Universidad le deniega la rematriculación para el segundo cuatrimestre. La Corte hace lugar al amparo y ordena la matriculación basándose en la obligación de garantizar "igualdad de oportunidades, mediante la supresión de todos los obstáculos determinados socialmente, ya san físicos, económicos, sociales o psicológicos que excluyan o restrinjan su plena participación en la sociedad”. Considera que las autoridades universitarias tenían conocimiento de la discapacidad de la demandada, debido a su notoriedad y por haberle otorgado una beca completa, "[...] en el centro educativo recurrido debió brindársele, oportunamente, a la agraviada los servicios de apoyo y las ayudas técnicas (así como las adecuaciones curriculares) que requería con el fin de garantizarle el ejercicio de su derecho a la educación”. Por ello, ordena a la Universidad que adopte las medidas necesarias y que ejecute las acciones pertinentes, a fin de facilitarle a la amparada el disfrute pleno de las adecuaciones curriculares que requiere en razón de su discapacidad.

Por su parte, la Corte Suprema de Justicia argentina se pronunció sobre el derecho a la educación de las personas con discapacidad en clave de obligaciones de prestación que debe realizar el Estado para garantizar igualdad de condiciones. En el caso Lifschitz, ${ }^{89}$ la Corte argentina ordenó al estado nacional otorgar un subsidio que permitiera solventar los gastos de educación y transporte de un niño discapacitado cuyos padres no contaban con recursos económicos suficientes y ante la falta de vacantes en las escuelas públicas y servicios de transportes especiales. La Corte sostuvo que era evidente que el sistema de transporte público no podía ser utilizado por quien no puede valerse por sí mismo y que era el Estado quien debía probar que había vacantes en los sistemas de educación pública. En consecuencia, resolvió que el Estado debía otorgar el subsidio hasta tanto demostrara que los padres del niño contaban con los medios económicos para sufragar estos gastos o que había vacantes en escuelas públicas especiales y un transporte público adecuado. La cuestión en el caso "Lifschitz" también presenta un tema de violación de la prohibición de discriminación porque todos los niños tienen derecho a acceder a la educación formal. Este niño se veía impedido de acceder a la educación por su situación de discapacidad. No había vacantes en las escuelas públicas cercanas y los medios de transporte no estaban preparados para que esta persona con discapacidad pudiera moverse por sus propios medios y así acceder a una escuela que responda adecuadamente a sus necesidades e intereses. Además, el niño se encontraba en desigualdad de condiciones de aquellos otros que poseían una obra social o subsidio estatal para la educación especial. 
En este caso, la discriminación se da por causa de su condición social sumado a que pertenece a un grupo vulnerable o desaventajado - personas con discapacidad, art. 75, inc. 23, $\mathrm{CN}-.90$

Respecto del tema de los subsidios para la educación especial, la Corte Constitucional Colombiana, en su sentencia C-559 de 2001, declaró la inexequibilidad de una parte de una norma que señala que los hermanos huérfanos de padre y los hijos inválidos o de capacidad física disminuida percibirían doble cuota del subsidio familiar si recibían educación o formación "profesional especializada" en establecimiento idóneo. La Corte consideró que el beneficio debería ser para todo tipo de formación - siempre y cuando fuera proporcionada por un establecimiento idóneo- y que no debía limitarse a que se tratara de un establecimiento especializado, es decir, encargado de manera exclusiva de la formación de personas con algún tipo de limitación. Puntualizó que las dificultades adicionales que puedan tener las personas con discapacidad en instituciones educativas ordinarias no justificaba que el beneficio en cuestión estuviera limitado a quienes optaban por instituciones educativas especializadas. Advirtió que:

[...] resulta pertinente reiterar la preceptiva reseñada, con arreglo a la cual los discapacitados deben ser acogidos por las instituciones educativas sin discriminación alguna, aplicando integralmente estrategias y métodos pedagógicos adecuados a las especiales características de dichos destinatarios, dentro de una prosecución epistemológica participativa que sin perder de vista las diferencias sustanciales que se dan cita en todos los grupos humanos, adelante los respectivos programas académicos buscando la satisfacción individual y colectiva de todos los alumnos, descartándose por tanto cualquier conato institucional o personal de otear a los discapacitados como "plantas exóticas" que se deben mantener a raya. ${ }^{91}$

Respecto de la educación inclusiva, la Corte Constitucional Colombiana es el tribunal superior de América Latina que mayor cantidad de jurisprudencia registra sobre el tema. En su sentencia T-429/92, trató el caso de una niña a quien se le condicionó el ingreso a tercer año de bachillerato a la presentación previa de los resultados de un encefalograma y un diagnóstico neurológico, por cuanto sus profesores consideraban que tenía dificultades de aprendizaje y, en consecuencia, requería educación especial. El juez de instancia concedió el amparo, pero dispuso que el padre de la niña debía demostrar, dentro del término de cuatro meses, que ella no precisaba educación especial. La Corte decidió que la permanencia de la niña en el bachillerato no podía estar condicionada a la aportación por parte de sus padres de prueba alguna que certificara si la niña requería o no atención especializada. Consideró que el derecho a la educación de los niños y las niñas es un derecho fundamental prevalente y que, por 
consiguiente, "el Estado debe asegurarles las condiciones necesarias para su acceso y permanencia en el sistema educativo". En este caso, adicionalmente, tuvo en cuenta que a la niña se le debía garantizar un proceso educativo que atendiera el principio de integración, esto es, en el sistema general de educación, por cuanto la segregación de los niños con algún tipo de limitación "sociocultural, psicoafectiva, cognoscitiva o neurocortical” en instituciones de educación especial implicaba una discriminación ya fuera directa o indirecta. Y con cita de su anterior jurisprudencia advirtió que:

Desde sus orígenes [los niños "con limitaciones"] son ubicados, con todas sus consecuencias, en el centro mismo del paradigma normal-anormal, con una alta carga de discriminación implícita o explícita, a la cual contribuye en buena medida la propia rotulación. Surge así, pues, una desigualdad que habrá de incidir negativamente en las oportunidades diversas ofrecidas a los niños, según que se hallen ubicados en los terrenos de la normalidad o de la anormalidad, respectivamente. [...] La educación ordinaria, por el contrario, es la que se ofrece a todos los niños sin reparar en sus eventuales limitaciones o necesidades especiales. Supone el acceso y permanencia al mundo de lo común y corriente, vale decir, de la cotidiana normalidad. Los procedimientos y prácticas pedagógicas son, pues, los requeridos para la formación del niño "normal" [...] La igualdad de oportunidades es no solo condición necesaria de la democracia constitucional contemporánea sino parte consubstancial del Estado social de derecho en que se ha transformado Colombia, por virtud de lo dispuesto en el artículo primero de su Constitución vigente. Implica no solo la ausencia de discriminaciones sino también ayuda efectiva para que quienes se encuentren en situación de inferioridad o desventaja puedan remediarlas eficazmente. ${ }^{92}$

Así, la Corte Constitucional Colombiana se pronunció en jurisprudencia constante por la formación escolar de los niños con discapacidad dentro del sistema general de educación, antes que en sistemas especiales que los aíslen, al considerar que la primera favorece en mayor medida la integración y rehabilitación de los niños y niñas a la sociedad ${ }^{93}$ resumida en la siguiente regla: las instituciones del sistema de educación general tienen el deber de permitir a las personas con discapacidad el acceso a tal derecho en entornos integrados, a fin de contribuir en su proceso de integración social, así ello implique un esfuerzo adicional razonable de su parte, pues tal proceso debe ser impulsado por directo mandato constitucional.

Respecto de las condiciones de acceso a los sistemas de salud, las personas con discapacidad suelen padecer la falta de financiación efectiva de los sistemas. Por ejemplo, en los países de ingresos altos, entre el 20\% y el 40\% de las personas con discapacidad no tienen cubiertas sus necesidades de asistencia para las actividades cotidianas. En 
muchos países de ingresos bajos y medianos, los gobiernos nacionales no pueden proporcionar servicios adecuados, y los proveedores comerciales de servicios no están disponibles o no son financieramente asequibles para la mayoría de las familias. ${ }^{94}$ Un análisis de la Encuesta Mundial de Salud de 2002-04, en 51 países señaló que las personas con discapacidad tenían más dificultades que las personas sin discapacidad para obtener exenciones o reducciones de los costos de atención de salud. En este sentido, la Corte Suprema de Justicia argentina posee una jurisprudencia copiosa referida al derecho a la salud. Varios de esos fallos encuentran como actores de la petición a personas con discapacidad (tratándose en la mayor parte de los casos de niños, ancianos o mujeres). Al respecto, el caso "Campodónico de Beviacqua contra Banco Nacional de Drogas Antineoplásicas"95 es representativo de esta jurisprudencia. En el caso se trataba de un niño en situación de discapacidad que padecía desde su nacimiento el mal de "Kostman". Desde entonces, recibía en forma gratuita del Banco Nacional de Drogas Antineoplásicas una medicación especial para posibilitar el tratamiento de la enfermedad grave que padecía en su médula ósea que disminuía sus defensas inmunológicas. Ese Banco informó a los padres del niño que iba a interrumpir la entrega de la medicación. Alegaba que el niño poseía obra social; que asimismo podía pedir un subsidio para la compra del medicamento al estado provincial — por encontrarse domiciliado en la Provincia de Córdoba- o al Estado Nacional a través del Ministerio de Desarrollo Social. Sostenía que si le seguía entregando el medicamento al niño le estaba sacando la posibilidad de otorgarlo a otras personas que padecen cáncer y que requieren esa medicación.

Los padres del niño iniciaron una acción de amparo contra el Estado Nacional, atacando la acción de interrupción de la droga. El caso llegó por apelación a la Corte Suprema quien ordenó al referido Banco a que siguiera entregando la droga. Este medio atacado (la interrupción) no era idóneo en el caso concreto para proteger en forma adecuada la salud del niño, su enfermedad seguía siendo grave y requería el medicamento en forma urgente. Por lo demás, si bien poseía la cobertura de una obra social, ésta no estaba en condiciones de otorgar el medicamento. Además, el niño no podía esperar a que se regularizara el funcionamiento eficaz de la obra social, ya que subsistía la situación de "urgencia y extrema necesidad que tenía el tratamiento prescripto para salvaguardar la vida y la salud del niño”, por la que el referido Banco Nacional de Drogas había decidido prestar asistencia al niño, hasta que resolvió interrumpir injustificadamente la entrega de la medicación. Por último, tampoco fue una razón de peso suficiente alegar que no se trataba de una enfermedad oncológica, porque si bien no lo era su tratamiento requiere de la misma droga que se necesita para el tratamiento de cáncer. Por ello, el niño se encontraría en la misma situación de hecho que los enfermos de cáncer que recibían la droga del Banco, siendo irrelevante el nombre de la enfermedad. La Corte esboza un argumento de igualdad cuando sostiene que al interrumpirse la prestación del medicamento prescripto para tratar su enfermedad el 
Estado estaba poniendo al niño con discapacidad por su condición social (que es otra de las causas de prohibición de discriminación), en desigualdad de condiciones respecto de aquellas personas que estaban en la misma situación de enfermedad o semejante y sí estaban recibiendo la medicación ya sea porque acceden por sus propios medios o se la estaba entregando la obra social, la empresa de medicina prepaga o el estado nacional o provincial. Desde el punto de vista de la relevancia de la situación, todos aquellos que padecen una enfermedad semejante, sea o no cáncer, y que necesitan alguna medicación, se encuentran en igualdad de condiciones. Si alguien recibe el medicamento y el niño no lo recibe, estamos en presencia de un trato desigualitario que no se sostiene con ninguna razón de peso. Por ello, el acto de interrupción de la medicación devino en arbitrario y contrario al mandato de igualdad.

Incluso, haciendo aplicación directa de la Constitución, se puede vislumbrar una tendencia jurisprudencial de la Corte argentina de ampliación de la obligación de cobertura integral de la salud de las personas con discapacidad que surge de las leyes para un sector del sistema de salud hacia el sector privado. Esta interpretación a favor de la actualización de las prestaciones surge además de la consideración del mandato constitucional del art. 75, inc. 23, CN, que identifica a las personas con discapacidad como un grupo vulnerable o grupo desaventajado que requiere de "medidas de acción positiva”. 96

Respecto de los derechos de las personas con discapacidad y la relación de empleo, la jurisprudencia de las Cortes y Tribunales de América Latina y el Caribe han generado abundante jurisprudencia respecto de los accidentes de trabajo, las licencias por enfermedad, las causales arbitrarias de despido, entre otras.

Por su parte, en la sentencia del 3 de julio del 2000, el Tribunal de amparo constitucional de Bolivia trató un amparo iniciado por una persona que padecía paraplejia parcial contra el Alcalde Municipal de Oruro. Peticionaba que se lo restituyera en el cargo del que había sido despedido y se le abonaren los daños y perjuicios pertinentes. Alegaba un trato discriminatorio por su discapacidad. El Tribunal, en su voto mayoritario, entendió que asistía razón al peticionante, pues: "los efectos de la discapacidad sobre una persona dependen de manera fundamental del entorno social, es decir, que la discapacidad no es únicamente un problema individual sino de la sociedad en general. Esto significa que un medio social negativo y poco auspiciador puede convertir la discapacidad en invalidez, y que por el contrario un ambiente social positivo e integrador contribuye de manera decisiva a facilitar y aliviar la vida de las personas afectada con una incapacidad", y "el propósito del Estado de hacer efectiva la protección de los derechos y garantías de las personas discapacitadas del país y proporcionarles una vida más llevadera dentro de sus limitaciones, como una obligación social que compromete tanto a las instituciones públicas como privadas".

En suma, la jurisprudencia sobre (des)igualdad de las personas con discapacidad, si bien habla de la prohibición de no-discriminación arbitraria, advierte sobre la 
importancia de las medidas de acción positiva. Este énfasis puesto en las obligaciones estatales de prestación positiva va de la mano de las interpretaciones realizadas por el Comité de DESC, que indican que el derecho a la salud de las personas con discapacidad no solo requiere que el Estado cumpla con sus obligaciones de respetar sino también de proteger y garantizar a través de un accionar positivo. En este sentido, las decisiones de las Cortes pueden ser interpretadas como partes del accionar positivo del Estado tendiente a lograr igualdad real de las personas con discapacidad para el ejercicio de sus derechos. Además, esta jurisprudencia otorga material argumentativo suficiente para reclamar por una mejor protección de sus derechos por la vía de las acciones de incidencia colectiva de las personas con discapacidad en situación de indigencia o pobreza.

\subsection{Orientación SeXual}

El reconocimiento — y gradual erradicación — de la discriminación por orientación sexual se ha visto determinado en América Latina y el Caribe por el contexto de instauración y consolidación de los estados de derecho y del lenguaje de los derechos humanos, que han favorecido la agenda regional en materia de sexualidad y reconocimiento de la diversidad. Por ejemplo, la Constitución del Ecuador es la segunda en el mundo en reconocer explícitamente la orientación sexual como una forma de discriminación, desde 1996 la Ciudad de Buenos Aires reconoce el "derecho a ser diferente” y la no-discriminación por género ni orientación sexual.97 En 2008, Nicaragua y Panamá despenalizan las relaciones homosexuales y, en 2009, Bolivia fue el primer país de la región en otorgar rango constitucional explícito a la prohibición de esta clase de discriminaciones. En este mismo sentido, la Asamblea Legislativa de la Ciudad de México aprobó el reconocimiento de las alianzas entre personas del mismo sexo bajo la figura del matrimonio y finalmente en julio del 2010 la Argentina lo hizo a nivel nacional, entre otros. ${ }^{98}$

Estos avances normativos, no obstante, requieren ser analizados a la luz de las prácticas discriminatorias, aún presentes en un continente marcado por una fuerte heteronormatividad. ${ }^{99}$ En este contexto, la aplicación jurisprudencial del principio de igualdad a los casos de discriminación por orientación sexual presenta ciertos avances importantes en la región que acompañan - y por momentos impulsan- - el gradual reconocimiento legislativo. En este sentido, el reconocimiento y el respeto de la diversidad sexual constituyen un aporte central a la discusión respecto de la interpretación del principio de igualdad, en tanto permite hacer explícita la diferencia entre igualdad y asimilación, tal como sucede en el fallo Alitt resuelto por la Corte Suprema argentina. ${ }^{100}$ En "Alitt", la cuestión debatida se refería a la denegación arbitraria de la personería jurídica de una asociación para la defensa de los derechos de los travestís y transexuales a la luz del derecho a la asociación de los arts. 14 y 19 de la CN. La cuestión presenta similitudes prima facie con el caso del 
derecho a casarse de las personas del mismo sexo, porque en ambos casos se trata del ejercicio de un derecho civil que expresa la voluntad de unión para el desarrollo de un proyecto común y no se les permite ejercerlo por la orientación sexual de los participantes. La Corte advierte en Alitt que si

no se otorga trascendencia alguna a una condición de base para una sociedad democrática como es la coexistencia social pacífica, cuya preservación asegura el amparo de las valoraciones, creencias y estándares éticos compartidos por conjuntos de personas, aun minoritarios, cuya protección interesa a la comunidad para su convivencia armónica. La renuncia a dicha función [...] traería aparejado el gravísimo riesgo de que solo aquellas valoraciones y creencias de las que participa la concepción media o la mayoría de la sociedad encontraría resguardo, y al mismo tiempo, determinaría el desconocimiento de otros no menos legítimos intereses sostenidos por los restantes miembros de la comunidad, circunstancia ésta que sin lugar a dudas constituiría una seria amenaza al sistema democrático que la Nación ha adoptado (arts. 1 y $33 \mathrm{CN}) .{ }^{101}$

En lo que respecta a la orientación sexual como categoría discriminatoria, se ha discutido si la misma exige aplicar un examen leve, intermedio o estricto de igualdad. En el caso de un examen de escrutinio estricto, la orientación sexual sería considerada una "categoría sospechosa" con las implicancias que este trae aparejado (principalmente presunción de inconstitucionalidad). Al igual que lo que sucede con la categoría "edad", esta distinción no ha sido incorporada expresamente en los instrumentos internacionales. Sin embargo, la Convención Americana de Derechos Humanos se refiere en su artículo 1 a que queda prohibida toda distinción fundada en "cualquier condición social". Muchos interpretan así, que por esto la orientación sexual no puede ser utilizada para perjudicar los derechos de las personas con una orientación sexual que no responde a la dominante. Así lo sostuvo la Corte Interamericana de Derechos Humanos en el caso Karen Atala e hijas, que comentaremos más adelante.

En este camino de reconocimiento, la Corte Colombiana, luego de haber rechazado numerosos reclamos de igualdad del colectivo GLBTTT, ${ }^{102}$ se pronuncia en la Sentencia C-075/07, reafirmando la línea jurisprudencial según la cual: (i) de acuerdo con la Constitución está proscrita toda forma de discriminación en razón de la orientación sexual; (ii) existen claras diferencias entre las parejas homosexuales y las parejas heterosexuales y, por lo tanto, no existe un imperativo constitucional de dar un tratamiento igual a unas y a otras; (iii) corresponde al legislador definir las medidas necesarias para atender la protección debida a los distintos grupos sociales y avanzar en la atención de aquellos que se encuentre en situación de marginación; 
(iv) toda diferencia de trato solo es constitucionalmente admisible si obedece al principio de razón suficiente; concluyendo que el carácter discriminatorio debe examinarse en cada caso concreto. En este caso, en el que se abordaban cuestiones tales como la afectación familiar de inmuebles, la obligación de prestar alimentos, derechos migratorios, garantía de no incriminación en materia penal, penal militar y disciplinaria, agravantes penales, derecho a la verdad y la justicia y a la reparación de crímenes atroces, prestaciones de salud y pensión en el régimen de la fuerza pública, subsidios familiares y de vivienda, acceso a la propiedad de la tierra y límites al acceso y ejercicio de la función pública, la Corte decidió que, efectivamente, se trataba de restricciones de carácter discriminatorio. Un año más tarde, en la sentencia C-336/08, respecto de la extensión del régimen patrimonial de las uniones de hecho heterosexuales a las uniones de hecho homosexuales, la Corte sostiene que, si bien las parejas del mismo sexo son diferentes a las parejas heterosexuales, y por ende es admisible un tratamiento diferencial por parte del legislador, la restricción del derecho a pensiones es, en este caso, lesiva de la dignidad humana y por ende constitucionalmente prohibida por discriminatoria.

Esta línea jurisprudencial ilustra el paso de la Corte Constitucional Colombiana desde la igualdad formal hacia la igualdad material, en la medida en que comienza a admitir, en ciertos casos, el cuestionamiento de las distinciones trazadas por el legislador. No obstante, ha sido superada en la región por jurisprudencia que ya aplica un examen estricto y desarrolla argumentos referidos a la igualdad como reconocimiento: El 22 de abril de 2009, José María Di Bello y Alex Freyre solicitaron turno para contraer matrimonio ante el Registro Nacional del Estado Civil y Capacidad de las Personas de la Ciudad Autónoma de Buenos Aires. Ante la negativa de la Administración, presentan una acción de amparo, resuelto favorablemente por el Juzgado de 1. Instancia en lo Contencioso Administrativo y Tributario n. 15, el día 10 de noviembre del mismo año. No obstante, la Administración decidió no realizar la ceremonia en función de una anulación declarada por un Juzgado Nacional de Familia. Finalmente, Freyre y Di Bello contrajeron matrimonio el día 28 de diciembre de 2009 ante el Registro Civil de la ciudad de Ushuaia, provincia de Tierra del Fuego gracias al Decreto n. 2.996/09 emitido por la entonces gobernadora Fabiana Ríos.

En Freyre se analiza si la prohibición legal que impide contraer matrimonio a dos personas del mismo sexo entre sí resulta discriminatoria. Con ese objeto, la jueza descarta en primer lugar la interpretación de la igualdad formal:

Que la igualdad que garantiza el artículo 16 de la Constitución, tal como lo interpreta el representante del GCBA, no importa otra cosa que la prohibición de que se establezcan exenciones o privilegios que excluyan a uno de lo que se concede a otro en iguales circunstancias. Su formulación 
resumida suele expresarse en el adagio: "igualdad entre iguales". Así entendido, este derecho estaría emancipado del principio de nodiscriminación, al dejar que el Estado determine la noción de igualdad que será fuente de derechos. Es decir, bajo el amparo de aquel principio se puede justificar la discriminación por origen racial, nacionalidad, por orientación o identidad sexual. Más aún, históricamente, el concepto de "iguales pero separados" ha servido como una forma de camuflar el repudio hacia grupos excluidos. ${ }^{103}$

Por otro lado, una interpretación plena del principio de igualdad supone previamente el derecho a ser quien se es, y la garantía de que el Estado solo intervendrá para proteger esa existencia y para contradecir cualquier fuerza que intente cercenarla o regularla severamente. De este modo, se identifica la orientación sexual como categoría sospechosa: "[...] entonces, la Constitución local reconoce y garantiza el derecho a ser diferente, no admitiendo discriminaciones que tiendan a la segregación por razones o por pretexto de orientación sexual (art. 11). Así, a fin de facilitar la impugnación de distinciones ilegítimas realizadas por el legislador, el constituyente de la Ciudad ha establecido una lista de clasificaciones sospechosas de ocultar motivos de distinción incompatibles con el principio de no-discriminación”. ${ }^{104}$ Por ello, "la distinción debe ser sometida a un escrutinio estricto, evaluación que implica una inversión en la carga de la prueba, de modo tal que es la parte que defiende la constitucionalidad de la norma la En este sentido, "la exclusión de los beneficios y responsabilidades del matrimonio [...] representa una forma radical de afirmar que la pareja de los actores no merece el pleno reconocimiento estatal... El principio de igualdad consiste, entonces, en el derecho a ser reconocidos como iguales y tratados dignamente. Es por eso que la opción contemplada en la ley 1.004 [unión civil] no basta, en el caso, para satisfacer el principio de igualdad”. ${ }^{105}$ Esta sentencia tiene particular relevancia porque nos habla de una interpretación del principio de igualdad en términos de reconocimiento, en una línea que ya había sido abierta por el fallo Alitt de la Corte Suprema argentina. ${ }^{106}$

En este mismo sentido, se expidió la Corte Suprema de Justicia de México respecto de la Acción de Inconstitucionalidad 2/2010. El 21 de diciembre de 2009, la Asamblea Legislativa del Distrito Federal modificó la redacción del art. 146 del Código Civil, reemplazando el texto "El matrimonio es la unión libre de un hombre y una mujer..." por el texto "el matrimonio es la unión libre de dos personas...”. Contra esta norma, la Procuraduría General de la República interpuso recurso ante la Suprema Corte de Justicia de la Nación, sosteniendo que la modificación realizada atentaba contra la definición tradicional de familia, era irrazonable e inmotivada - puesto que la restricción del derecho a casarse a parejas heterosexuales no implicaba una restricción de derechos respecto de aquellos con otras orientaciones 
sexuales - y, por último, que con la reforma el estado mexicano se estaría alejando del deber de salvaguarda del interés superior del niño. En su sentencia, la Suprema Corte afirmo que: "El valor superior que se persigue con el principio de igualdad consiste en evitar que existan normas que, llamadas a proyectarse sobre situaciones de igualdad de hecho, produzcan, como efecto de su aplicación, la ruptura de esa igualdad, al generar un trato discriminatorio entre situaciones análogas, o bien, propicien efectos semejantes sobre personas que se encuentran en situaciones dispares, lo que se traduce en desigualdad jurídica" (párr. 134). Agrega que "el principio de igualdad, en lo que atañe a la protección de la familia [...] es la familia como realidad social y que, por tanto, tal protección debe cubrir todas sus formas y manifestaciones en cuanto la realidad existente alcanzando a dar cobertura a aquellas familias que se constituyan por el matrimonio; por uniones de hecho; por un padre o una madre e hijos (familia monoparental), o bien, por cualquier otra forma que denote un vínculo similar" (párr. 137). Por otro lado, rechaza de plano la Corte la posibilidad de aceptar otras formas de reconocimiento, afirmando que “(p)or el contrario, la decisión tomada por la Asamblea Legislativa del Distrito Federal para reconocer el derecho a las personas de contraer matrimonio con otra persona de su mismo sexo, dada su orientación sexual, se corresponde con los diversos derechos fundamentales [...], y les permite alcanzar de manera efectiva la protección jurídica reforzada de su unión o vínculo, tal como ocurre con las parejas heterosexuales, pues son relaciones que tienen las mismas características (afectividad, sexualidad, solidaridad, estabilidad, permanencia, proyecciones comunes, etcétera), por lo que, contrario a lo afirmado por el Procurador General de la República, sí es el medio idóneo para reconocer en ese rubro la igualdad entre los individuos, sean heterosexuales u homosexuales y/o lesbianas, al motivarlos las mismas razones para contraer matrimonio, como es esencialmente la de unirse legalmente para formar una vida en común y adquirir obligaciones entre sí y derechos derivados de tal vínculo, con el reconocimiento social de ese unión. Sin que sea válido sostener que puedan alcanzarlo a través de diversas formas establecidas legalmente, pues ello implica de suyo, negarles el acceso a una protección jurídica real, por su orientación sexual, o considerar que dichas uniones son de menor valor" (párr. 158). De este modo, la Corte destaca el déficit de reconocimiento y la necesidad de reparación suficiente, excluyendo medidas intermedias que resuelven aspectos redistributivos, pero dejan intacto los aspectos simbólicos de la discriminación:

En este sentido, la unión civil para las parejas de igual sexo, seguiría implicando discriminación porque no implica iguales derechos materiales ni reconocimiento en comparación con las que están habilitadas para el matrimonio. A su vez, la solución de iguales derechos para todas las parejas pero con nombre diferente a la institución matrimonial para parejas de 
igual sexo sigue siendo expresión de instrumento de discriminación por la sola orientación sexual. La historia de la lucha por el reconocimiento de los grupos discriminados advierte que el nombre no es neutral. Cuando se discutía la inclusión de las mujeres para el ejercicio del derecho al voto, algunos alegaban que se debía hacer pero con otro nombre, lo cual implicaba persistir en la desigualdad simbólica. ${ }^{107}$

De ambas sentencias surge con claridad la necesidad de conectar los principios de igualdad y de autonomía: "En tren de analizar las razones no-discriminatorias que puede tener el legislador cuando reglamenta el matrimonio, se podría pensar en clave de finalidad asociativa, es decir: otorgar protección jurídica a la unión voluntaria de dos personas mientras dure la relación”. Entonces, para promover la finalidad asociativa, se deberían modificar las normas del derecho civil para incluir el reconocimiento del matrimonio igualitario. ¿Por qué excluirlo? El único "pretexto” que les queda a quienes están en contra del matrimonio igualitario es la "orientación sexual” y esto implica dominación de quienes tienen una orientación dominante por sobre los otros. De esta manera, se está privilegiando una interpretación de matrimonio desde un patrón cultural en parte dominante, pero no único y que responde a un posible modelo de decisión autónoma. El problema es la falta de reconocimiento de la diversidad. ${ }^{108}$

“Así, la exclusión viola el principio de autonomía y diferencia. La voluntad de contraer matrimonio solo podría darse entre un varón y una mujer. Esta interpretación se basa sobre una concepción del bien común que apelaría a la 'moral' como 'moral de la mayoría'. Sin embargo, esta interpretación no pasaría, según entiendo, el test de constitucionalidad estricto que exigiría cualquier constitución que reconozca como principio estructurante el de autonomía [...] Se trataría del derecho fundamental de vivir libremente la condición de 'pareja', obteniendo - en los tiempos, formas y límites establecidos por la ley_ el reconocimiento jurídico con los derechos conexos y deberes ... ${ }^{109}$ [...] ¿Qué implica la autonomía? La posibilidad de determinar el propio plan de vida de acuerdo con las creencias, cosmovisiones de cada persona, de acuerdo con sus propios estándares morales, esto incluye la decisión de vivir o no en pareja. [...] Por todo ello, sostengo que la exclusión a las parejas del mismo sexo de la posibilidad que se otorga a las de distinto sexo viola el principio de igualdad constitucional y justifica una obligación de hacer suficiente del legislador (desarrollo legislativo y, en su defecto, de activismo judicial) en ordenamientos jurídicos que reconocen como principios estructurantes el de igualdad y el de autonomía”. ${ }^{110}$ Esta línea ha sido continuada por otros tribunales de la región. Así en la acción de inconstitucionalidad (ADI) 4.277, y ante una serie de demandas presentadas por parejas en orden a ser reconocidas con los mismos derechos que las uniones heterosexuales, el Superior Tribunal Federal de Brasil concluyó que las relaciones homoafectivas deben ser reconocidas como entidades familiares, y deben por 
ende ser legalmente reconocidas en igualdad de condiciones. El argumento del tribunal se asienta sobre el silencio constitucional respecto de la elección sexual y el principio de reserva, para afirmar que la redacción del art. 1.723 del Código Civil no puede negar a las uniones homoafectivas su carácter de familias, sin vulnerar el principio de igualdad, haciéndoles efectiva la protección constitucional relativa a las familias y todos los derechos que de ésta se desprenden. La importancia del fallo radica en su carácter vinculante para los tribunales inferiores. En una línea similar, aunque con mayor timidez, la Corte Constitucional Colombiana se ha pronunciado en la sentencia C-577/11, respecto de la exequibilidad de las normas que restringen el matrimonio a parejas heterosexuales. La Corte afirma que si bien ha venido reconociendo de modo gradual los mismos derechos a parejas conformadas por personas del mismo sexo, quedan todavía situaciones sin resolver. Al respecto se pronuncia a favor de la exequibilidad de dicho art. 113 del CC, instando al Congreso a legislar respecto de los derechos de las parejas homosexuales. Si bien la Corte considera que se trata de realidades distintas y que la determinación de un tratamiento diferencial es posible para el legislador, afirma que el desconocimiento de los derechos de estas parejas es discriminatorio, y de no legislarse antes de junio del 2013, éstas podrán concurrir ante notario o juez competente a fin de formalizar su unión.

En este tema se expidió la CIDH en el caso Karen Atala, que llega a la instancia internacional cuando la Corte Suprema de Chile resolvió en una demanda de tuición a favor del padre, quien solicitaba la tenencia de sus tres hijas menores, ya que su madre (y ex mujer) había comenzado una nueva relación con una mujer, con la que se encontraba viviendo. Dejando de lado diversos informes que hablaban respecto de que la convivencia en un hogar homosexual no causa perjuicio a los menores, como asimismo informes que se habían producido en el mismo proceso, respecto de la correcta situación en la que se encontraban las niñas viviendo con su madre, la Corte Suprema de Chile decide entregar las niñas a su padre, y sacarlas del cuidado de su madre. El caso se presenta ante la $\mathrm{CIDH}$, que sostiene que debía aplicarse un examen estricto de igualdad pues la discriminación se fundaba en una categoría sospechosa: la orientación sexual. Sostiene que, detrás del argumento de proteger el interés de las niñas, se encuentra un acto de abierta discriminación por la orientación sexual de la Sra. Atala. Este caso fue presentado por la CIDH ante la Corte IIDH, el 17 de septiembre del 2010, encontrándose pendiente de resolución. ${ }^{111}$

En este sentido, puede verse un progreso en la jurisprudencia de la región: la aceptación dócil de la distinción trazada por el legislador que aparece en algunos de los primeros fallos de la Corte Constitucional de Colombia, supone una concepción formal del principio de igualdad, a través de la cual el tribunal no cuestiona la distinción trazada por el legislador. A partir de la sentencia C-075/07, el examen de igualdad pone en cuestión ya las razones en las que se fundamenta la clasificación trazada por el legislador, dando paso a la fórmula de igualdad jurídica material y al 
principio de no-discriminación arbitraria. No es, sin embargo, hasta los fallos más recientes, que el principio de igualdad es aplicado en términos de reconocimiento, de acuerdo al cual únicamente el otorgamiento de no solo de los mismos derechos, sino de los mismos nombres, es necesario para satisfacer el principio de igualdad.

De este modo, se han ido elaborando ciertas reglas a través de la jurisprudencia que podrían servir de guía para el resto de los países que aún se encuentran debatiendo estos tópicos. Por un lado, que la orientación o la identidad sexual constituyen categorías sospechosas, y toda diferencia en el trato requiere una fundamentación rigurosa por parte de la Administración cuando se utiliza a la clasificación para perjudicar los derechos del grupo históricamente excluido. Por otro lado, la discriminación por causa de la orientación o identidad sexual no solo implica un problema de redistribución, sino también de reconocimiento, por lo cual la mera equiparación de derechos patrimoniales no solo no puede ser considerada reparación suficiente sino que la atribución de derechos, cuando niega el reconocimiento de la identidad, constituye un agravamiento de la desigualdad.

\subsection{Pobreza}

En un continente atravesado por múltiples desigualdades, la inequitativa posesión de los recursos materiales es, probablemente, una de las más extendidas; y no obstante los avances en materia de distribución de los últimos diez años, el panorama regional en términos de pobreza y exclusión social es preocupante: uno de cada tres habitantes de América Latina y el Caribe se encuentra por debajo de la línea de pobreza, y uno de cada diez por debajo de la línea de indigencia. ${ }^{112}$ No obstante, aun cuando parece claro que nos enfrentamos a una cuestión de aplicación del principio de igualdad, ${ }^{113}$ la pobreza es habitualmente abordada en términos de incumplimiento de cada uno de los derechos económicos, sociales y culturales, lo que dificulta su abordaje como un problema integral. ${ }^{114}$ Nino afirma que "desde los institutos legales, la pobreza no está enfocada como una cuestión de discriminación sino como una mera realidad socioeconómica que hay que enfrentar con herramientas de ese mismo tipo. El derecho solo está presente — de manera intermitente y a partir de reclamos aislados- cuando hay vulneraciones manifiestas de derechos básicos, como el acceso al agua o a la alimentación”. 115

En ese sentido, y sin pretender agotar los desarrollos jurisprudenciales referidos al tema, analizaremos algunas sentencias recientes que abordan la pobreza desde la perspectiva de los principios de igualdad y no sometimiento.

De los fallos recientes en la materia se destacan la sentencia T-025/04 de la Corte Constitucional Colombiana, el caso Servellón García resuelto por la Corte IDH y hemos decidido incluir una decisión de primera instancia de Argentina por su carácter novedoso en términos de abordaje jurisdiccional de la pobreza. En el primer caso, la pobreza o indigencia es analizada como el síntoma o efecto de un trato 
discriminatorio por parte del Estado. En el segundo caso, la vulneración del principio de igualdad ocurre porque la pobreza convierte a un determinado colectivo en blanco de prácticas estatales represivas que no se extienden al resto de la sociedad. El tercer caso es similar al primero, pero en lugar de justificar prácticas estatales ilegales, la pobreza convierte a un determinado colectivo en destinatario de políticas públicas que de por sí constituyen prácticas discriminatorias.

En la sentencia T-025/04 sobre población desplazada, la Corte Constitucional Colombiana utiliza la categoría "estado de cosas inconstitucional” para describir la situación en que viven más de tres millones de personas desplazadas por la violencia en Colombia; resolviendo que la incapacidad estatal para impedir la vulneración masiva, generalizada y sistemática de derechos constitucionales implica una situación de dominación incompatible con los estándares del estado democrático de derecho. Así la Corte Constitucional afirma que ha sido vulnerado "(e)l derecho a la igualdad, dado que (i) a pesar de que la única circunstancia que diferencia a la población desplazada de los demás habitantes del territorio colombiano es precisamente su situación de desplazamiento, en virtud de ésta condición se ven expuestos a todas las violaciones de los derechos fundamentales que se acaban de reseñar, y también a discriminación y (ii) en no pocas oportunidades, el hecho del desplazamiento se produce por la pertenencia de la persona afectada a determinada agrupación o comunidad a la cual se le atribuye cierta orientación respecto de los actores en el conflicto armado y por sus opiniones políticas, criterios todos proscritos como factores de diferenciación por el artículo 13 de la Carta”. ${ }^{116}$ A partir de este diagnóstico, la Corte descarta la perspectiva formal sobre la igualdad, afirmando la necesidad de la intervención estatal ante desequilibrios estructurales puesto que "[...] a menos que las limitaciones y desigualdades reales a las que el hombre está sujeto en su vida cotidiana sean efectivamente contrarrestadas mediante actuaciones positivas y focalizadas por parte de las autoridades, la libertad e igualdad del ser humano no dejarán de ser utopías abstractas. Es por ello que se acepta que, en muchos casos, la libertad y la igualdad requieren para su realización de medidas, acciones, prestaciones, servicios, que la persona, por sí misma, no puede asegurar. El Estado de derecho evolucionó así, de un estado liberal democrático a uno social, también democrático, animado por el propósito de que los presupuestos materiales de la libertad y la igualdad para todos estén efectivamente asegurados". ${ }^{117}$ En este contexto, una aplicación del principio de igualdad en clave de redistribución requiere de la intervención activa del Estado en la corrección de la desigualdad analizada: "En razón de esta multiplicidad de derechos constitucionales afectados por el desplazamiento, y atendiendo a las aludidas circunstancias de especial debilidad, vulnerabilidad e indefensión en la que se encuentran los desplazados, la jurisprudencia constitucional ha resaltado que éstos tienen, en términos generales, un derecho a recibir en forma urgente un trato preferente por parte del Estado, en aplicación del mandato constitucional según el cual: "el grupo social de los desplazados, 
por su condición de indefensión merece la aplicación de las medidas a favor de los marginados y los débiles, de acuerdo con el artículo 13 de la Constitución Política, incisos $2 .^{\circ}$ y $3 .^{\circ}$ que permiten la igualdad como diferenciación, o sea la diferencia entre distintos". Este punto fue reafirmado en la Sentencia T-602/2003, en la cual se dijo que "si bien el legislador y las entidades gubernamentales deben tratar de igual modo a todas las personas, pues así lo estipula el artículo 13 de la Constitución, las víctimas del fenómeno del desplazamiento forzado interno sí merecen atención diferencial". Este derecho al trato preferente constituye, en términos de la Corte, el "punto de apoyo para proteger a quienes se hallan en situación de indefensión por el desplazamiento forzado interno", y debe caracterizarse, ante todo, por la prontitud en la atención a las necesidades de estas personas, ya que "de otra manera se estaría permitiendo que la vulneración de derechos fundamentales se perpetuara, y en muchas situaciones, se agravará". ${ }^{118}$ En este caso, la vulneración del principio de igualdad produce la situación de pobreza, lo que, de acuerdo con la Corte, pone en cabeza del Estado la obligación de resolver la situación de desigualdad material derivada del trato de sometimiento.

En otros casos, como en Servellón García y otros contra Honduras, la pobreza opera como causa de sometimiento: en septiembre de 1995, la policía hondureña detuvo a Marco Antonio Servellón García, Rony Alexis Betancourt, Orlando Álvarez Ríos y Diómedes Obed García, quienes, luego de ser sometidos a golpizas y malos tratos, fueron ejecutados por las fuerzas de seguridad. Si bien el caso en sí mismo puede aparecer como un episodio aislado de violencia policial, la Corte IDH lo ubica en el marco de prácticas estatales sistemáticas de represión, puesto que, entre 1995 y el año 2002, 904 niños pobres fueron ejecutados por las fuerzas de seguridad. El caso tiene particular relevancia en tanto identifica y pone de manifiesto una clase de dominación ampliamente extendida en la región, vinculada al accionar represivo de las fuerzas de seguridad, dirigido principalmente contra individuos jóvenes y de escasos recursos. ${ }^{119} \mathrm{Si}$ bien la Corte IDH ya se había pronunciado en un caso previo $^{120}$ es en esta oportunidad que introduce la cuestión de la igualdad para dar cuenta de dichas prácticas represivas. Así afirma la Corte IDH: "En ese sentido, el Estado no puede actuar en contra de un determinado grupo de personas, ya sea por motivos de género, raza, color, idioma, religión o convicción, opinión política o de otra índole, origen nacional, étnico o social, nacionalidad, edad, situación económica, patrimonio, estado civil, nacimiento o cualquier otra condición”. ${ }^{121}$ Además, identifica una suerte de "iteración" de la desigualdad: "La Corte advierte que, en atención al principio de igualdad ante la ley y no-discriminación, el Estado no puede permitir por parte de sus agentes, ni fomentar en la sociedad prácticas que reproduzcan el estigma de que niños y jóvenes pobres están condicionados a la delincuencia, o necesariamente vinculados al aumento de la inseguridad ciudadana. Esa estigmatización crea un clima propicio para que aquellos menores en situación de riesgo se 
encuentren ante una amenaza latente a que su vida y libertad sean ilegalmente restringidas”. ${ }^{122}$ De este modo, la desigualdad material existente se convierte en causa de estigmatización, que a su vez preserva y refuerza la desigualdad original.

Por último, el caso de "aulas container"123 el test de igualdad no es aplicado a un “estado de cosas desigualitario" sino a la política pública desarrollada por el Estado para resolverlo. A lo largo del año 2002, y como medida provisoria para satisfacer el crecimiento de la demanda de espacio en instituciones educativas públicas, el gobierno de la Ciudad Autónoma de Buenos Aires comenzó a instalar "aulas" modulares (containers) ${ }^{124}$ en escuelas cercanas a villas de emergencia. La política, sin embargo, se mantuvo con el correr de los años, y a fines del año 2005 el número de "aulas container" había ascendido a 15 y no existían planes concretos de su respectivo reemplazo. ${ }^{125}$ A esto se suma que esta clase de instalaciones solo era utilizada en las inmediaciones de las denominadas "villas de emergencia", y no en el resto de la ciudad. Un reclamo interpuesto por una ONG consiguió que se ordenara a la administración el retiro de dichas aulas, confirmando la existencia de una situación de discriminación por condición socioeconómica. Lo relevante de esta sentencia es que el test de igualdad se aplica en conjunto con el de satisfacción del derecho a la educación. El accionar insuficiente del estado es injustificado aun cuando la Administración aduzca la realización de una medida de acción positiva en orden a paliar un déficit de derechos: "[...] la demandada parece aducir que el dictado de clases en las condiciones antes aludidas en escuelas cercanas a 'villas miseria' no constituye una discriminación en relación con quienes en ellas moran, sino, muy por el contrario, sería demostrativo de una intención de dictar clases especialmente para tal universo de personas, aún frente a la inexistencia en la actualidad de infraestructura a tales efectos. Pues bien: no dudo de que no existe por parte de la Ciudad un ánimo discriminatorio; pero la discriminación existe. Es que aun con la valorable finalidad expresada por la demandada, existen 'soluciones' que no pueden adoptarse por cuanto no resisten el control de razonabilidad planteado en los presentes actuados". ${ }^{126}$ En verdad, si bien la sentencia habla de falta de razonabilidad, se está realizando un examen de suficiencia o adecuación de la acción estatal implementada. El fallo es de suma importancia, pues cuando la obligación estatal es de hacer, el fallo advierte que no alcanza con que se haga algo sino que ese accionar estatal positivo debe ser adecuado y suficiente. De esta manera, para determinar si el accionar del Estado es "adecuado", se requiere no solo que el Estado haya hecho algo, sino que ese hacer debe lograr alcanzar el fin perseguido, esto es, gozar del derecho a la educación en condiciones de igualdad (entendida como el principio de no sometimiento) y, al aplicarse un escrutinio bien intensivo, esa adecuación medio-fin debe ser muy fuerte.

La pobreza y en particular la pobreza extrema comienzan a ser consideradas por la jurisprudencia como un obstáculo para el ejercicio pleno de la autonomía de los individuos, y además de constituir una vulneración de los estándares mínimos 
en materia de Derechos Económicos Sociales y Culturales. De esta manera, se la entiende de modo integral, como un quiebre del principio de igualdad. Estos avances denotan un progreso en la fórmula predominante de igualdad, que es cada vez más comprensiva, que exige del Estado medidas de acción positiva ante situaciones de desigualdad material. Por otro lado, la jurisprudencia de la región también ha resuelto que no cualquier medida destinada a paliar la desigualdad puede ser considerada apropiada, proscribiendo la discriminación no solo en el estado de cosas, sino también en los medios elegidos por el Estado.

\section{CONCLUSIONES}

La jurisprudencia de los tribunales y cortes constitucionales de los diversos Estados de América Latina y el Caribe devela que si bien el modelo de igualdad como no-discriminación está arraigado, cierta tendencia jurisprudencial demuestra que es posible pensar los tribunales como foros de discusión para plantear reclamos igualitarios en clave de no-dominación.

Estas son las tendencias que nos interesa resaltar: en lo que respecta a la discriminación por la nacionalidad, parece haber un enriquecimiento desde el modelo con el cual se resuelven los casos, a la vieja aplicación del principio de igualdad en términos liberales, se le sumaría una comprensión más amplia, en términos de reconocimiento de desigualdades estructurales, sobre todo en los casos de etnia y migrantes. En lo que respecta a la edad como categoría de discriminación, la jurisprudencia parece seguir los mismos pasos, reconociendo la desigualdad estructural que afecta principalmente a personas de edad avanzada y niños o niñas en situación de pobreza.

Sin embargo, tanto respecto de discapacidad como de afrodescendientes pareciera que si bien el modelo desde el cual se resuelven los casos se ha ido modificando, interpretándose la igualdad desde la concepción de no sometimiento, dichas resoluciones resultan todavía muy focalizadas, atendiendo solo a una persona o un grupo determinado, pero sin detectar que quienes padecen la situación de discriminación requieren de soluciones más amplias _ estructurales_- tornándose ineficaces las acciones positivas o de discriminación inversa que se han adoptado.

Sobre orientación sexual, se percibe claramente una evolución de la jurisprudencia bastante sostenida hacia una aplicación del principio de igualdad en términos de reconocimiento. A pesar de que esta tendencia no sea una regla en la región, las expectativas son altas respecto del pronunciamiento de la Corte IDH en el primer caso que le ha llegado sobre discriminación por la orientación sexual. De esta manera, dicho órgano tiene la posibilidad por medio de su sentencia de hacer oír la voz de miles de personas que luchan por el reconocimiento.

Por último, si bien la aplicación del examen de igualdad para resolver situaciones de desigualdad material por pobreza, indigencia o miseria es aún incipiente en la 
región, es posible registrar algunos avances en este sentido. Esto insinúa un debilitamiento de la concepción liberal de la igualdad.

Son estas tendencias las que empiezan a mostrar que el derecho puede ser utilizado también como instrumento emancipador. No olvidamos, no obstante, que el tratamiento legal de las desigualdades puede generar nuevas desigualdades. En este sentido, quizá el derecho se torne insuficiente por sí mismo para superar la paradoja igualdad/desigualdad que padecen las sociedades, sin embargo queremos destacar a lo largo de este trabajo que la lectura del concepto de igualdad como mera igualdad formal se queda a mitad de camino a la hora de dar cuenta de la desigualdad estructural que padecen ciertos grupos, por lo menos cuando trabajamos desde herramientas jurídicas argumentativas.

: ARTIGO APROVADO (15/05/2013) : RECEBIDO EM 21/10/2011

\section{NOTAS}

1 Un agradecimiento especial a Margarita Maxit, Sergio Mohadeb, Rodolfo Arango, Claudia Escobar, Evorah Cardoso, Rafael Bellem de Lima y Berenice Orta Flores por darnos sus pareceres sobre los fallos relevantes de la jurisprudencia de los tribunales consultados. Asimismo agradecemos a Federico De Fazio por la lectura crítica y comentarios sobre este texto.

2 Carlos Barba Solano; Néstor Cohen, "Perspectivas críticas sobre la cohesión social”. Desigualdad y tentativas fallidas de integración social en América Latina, CLACSO, Buenos Aires, 2011, p. 11-12.

3 Ver Laura Clérico y Martín Aldao, "La igualdad como redistribución y como reconocimiento: derechos de los pueblos indígenas y Corte Interamericana De Derechos Humanos”. Estudios constitucionales. 2011, v. 9, n. 1.

4 Carlos Barba Solano; Néstor Cohen, "Perspectivas críticas sobre la cohesión social". Desigualdad y tentativas fallidas de integración social en América Latina, CLACSO, Buenos Aires, 2011, p. 11-12.

5 Desarrollado en el marco del proyecto de investigación UBACyT "La formación de jueces: perfiles y pertinencia en relación con un modelo de sociedad igualitaria”.

6 Roberto Saba, “(des)Igualdad estructural”. En Gargarella/Alegre, El derecho a la igualdad: aportes para un constitucionalismo igualitario, Buenos Aires, 2007.

7 La injusticia socioeconómica arraigada en la estructura político-económica de la sociedad respecto de la distribución de bienes (ejemplos de este tipo de injusticia se pueden vislumbrar en la explotación laboral, la marginación económica, la privación de los bienes materiales indispensables para llevar una vida digna, entre otros). Ver Laura Clérico y Martín Aldao, "La igualdad como redistribución y como reconocimiento: derechos de los pueblos indígenas y Corte Interamericana De Derechos Humanos”. Estudios constitucionales, 2011, v. 9, n. 1.

8 La otra deviene de la injusticia cultural o simbólica, arraigada en los patrones sociales dominantes en una sociedad desde los que se interpreta con pretensión de "uniformidad", por ejemplo, cuál es la forma de matrimonio 
que debe ser reconocida sin que la voz concreta de quienes tienen una orientación sexual diferente y diversa sea escuchada en el proceso de decisión (así, ejemplos de este tipo de injusticia son la dominación cultural, el no reconocimiento y el irrespeto e incluye la discriminación a lesbianas, gays, travestis, personas trans, bisexuales, entre otros).

9 Agradecemos a los evaluadores anónimos cuyas observaciones permitieron enriquecer esta sección del trabajo.

10 Ver Rafaele de Giorgi, "Direito, democracia e risco: vínculos com o futuro", Porto Alegre, Sergio Antonio Fabris Editor, 1998, p. 114. Es relevante señalar que el autor aborda el derecho desde la perspectiva de N. Luhmann, excluyendo de plano toda posibilidad de análisis práctico o normativo del mismo. Por el contrario, el presente trabajo se inscribe en una línea que podríamos denominar de "normativismo discursivo o débil”, abierta por J. Habermas y R. Alexy entre otros.

11 Ibid., p. 116 y 118.

12 Por ejemplo, es evidente que un Estado discrimina (distingue) al restringir la posibilidad de conducir automóviles a aquellos individuos que hayan tramitado el registro correspondiente, pero también es evidente (al menos dentro de nuestros cánones) que una diferenciación como ésta es perfectamente razonable, y más aún incluso deseable. Pero esto no es así porque las personas deban en todo tiempo y lugar obtener una autorización del Estado para hacer cosas, sino porque la razón en la que se apoya la distinción, esto es, la importancia de garantizar que todos aquellos que pueden utilizar un vehículo potencialmente peligroso deben haber demostrado antes su capacidad para hacerlo, no parece ser cuestionada. Si por el contrario el criterio para otorgar registros de conducir no fuera técnico, si por ejemplo algún colectivo fuera sistemáticamente reprobado en dichos exámenes, entonces se generaría una interpelación al derecho, una demanda de igualdad a partir de la cual tendría sentido abrir el debate sobre distinción cuestionada.

13 Robert Alexy, Teoría de los derechos fundamentales. Madrid, 2007, p. 351.

14 Robert Alexy, Teoría de los derechos fundamentales. Madrid, 2007, p. 360.

15 Cfr. Corte IDH, OC-18/03 (2003), párr. 89; OC-17/02 (2002), párr. 46; y OC-4/84 (1984), párr. 56. Esto genera diversas obligaciones a los Estados tienen la obligación de no introducir en su ordenamiento jurídico regulaciones discriminatorias, eliminar las regulaciones de carácter discriminatorio, combatir las prácticas de este carácter y establecer normas y otras medidas que reconozcan y aseguren la efectiva igualdad ante la ley de todas las personas.

16 Con palabras de la Corte Constitucional Colombiana en la sentencia T-093/2001 el juicio integrado de igualdad: "intentaría utilizar las ventajas analíticas de la prueba de proporcionalidad, por lo cual llevaría a cabo los distintos pasos propuestos por ese tipo de examen: adecuación, indispensabilidad y proporcionalidad stricto sensu. Sin embargo, conviene que la Corte proceda a graduar en intensidad cada uno de los distintos pasos del juicio de proporcionalidad, retomando así las ventajas de los tests estadounidenses. Así por ejemplo, si el juez concluye que, por la naturaleza del caso, el juicio de igualdad debe ser estricto, entonces el estudio de la 'adecuación' deberá ser más riguroso, y no bastará que la medida tenga la virtud de materializar, así sea en forma parcial, el objetivo propuesto. Será necesario que ésta realmente sea útil para alcanzar propósitos constitucionales de cierta envergadura. Igualmente, el estudio de la 'indispensabilidad' del trato diferente también puede ser graduado. Así, en los casos de escrutinio flexible, basta que la medida no sea manifiesta y groseramente innecesaria, mientras que en los juicios estrictos, la diferencia de trato debe ser necesaria e indispensable y, ante la presencia de restricciones menos gravosas, la limitación quedaría sin respaldo constitucional”.

17 V. Robert Alexy, Teoría de los derechos fundamentales. Madrid, 2007); Laura Clérico, Die Struktur der Verhältnismässigkeit. Baden Baden, 2001 [en castellano: Laura Clérico, El examen de proporcionalidad en el derecho constitucional. Buenos Aires, 2009]; Carlos Bernal Pulido, El principio de proporcionalidad y los derechos fundamentales. Madrid, 2007.

18 V. Alberto Garay, "Derechos civiles de los extranjeros y presunción de inconstitucionalidad de las normas". La Ley, 1989-B, p. 931; Enrique Bianchi, y Hernán Gullco, "La cláusula de igualdad: hacia un escrutinio más exigente”. Jurisprudencia Argentina, 2001, v. I, p. 1241; Laura Clérico y Sebastián Schvartzman, “'Repetto’ re-visitado: a propósito del fallo del Tribunal Superior de la Ciudad de Buenos Aires sobre acceso a la docencia en el caso de los extranjeros". En Gargarella/Alegre, El derecho a la igualdad: aportes para un constitucionalismo igualitario. Buenos Aires, 2007; 
Guillermo Treacy, "La utilización de categorías sospechosas como técnica para controlar la discriminación hacia los extranjeros". Jurisprudencia Argentina, 2006-IV-603; Roberto Gargarella "Cómo no debería pensarse el derecho a la igualdad. Un análisis de las opiniones disidentes en el fallo 'Reyes Aguilera'”. Jurisprudencia Argentina, 2007, v. IV, p. 67-74; Laura Clérico, "El derecho a la alimentación de los niños, la presunción de exclusión y la necesidad de cambiar el estándar de control de las obligaciones estatales iusfundamentales. 'Rodríguez', 'Comunidad toba del Chaco' y la sombra de Ramos". Jurisprudencia Argentina, 2007, v. IV, n. 6; Gustavo Maurino, "Pobreza y discriminación: la protección constitucional para los más humildes", en Gargarella/Alegre, El derecho a la igualdad: aportes para un constitucionalismo igualitario. Buenos Aires, 2007. Dulitzky reconstruye el examen de igualdad en el contexto interamericano como principio antidiscriminatorio e incluyendo "categorías sospechosas"; ver Ariel Dulitzky, "El principio de igualdad y no-discriminación. Claroscuros de la jurisprudencia interamericana”. Anuario de Derechos Humanos, 2007, n. 3 .

19 En palabras del Tribunal Supremo de Justicia de Venezuela, la carga de la prueba y de la justificación requiere: “a) la necesidad de la probanza plena de la justificación, probadamente necesarísimo y probadamente eficaz para el objetivo importante, necesario e indispensable; b) la necesidad fundamental, cuya realización se hace necesaria de la exigencia de la condición discriminatoria requerida; c) el carácter predictor que tal condición posee para alcanzar ambas necesidades, mediante métodos profesionalmente probados y aceptados y, d) la imposibilidad de alcanzar los objetivos señalados sin el establecimiento de la condición discriminatoria y la inexistencia de otro medio, vía o condición mediante el cual sería sustancialmente efectivo alcanzar tales objetivos, sin incurrir en la situación discriminatoria prohibida o menos discriminatoria que la derivada de la condición de igual naturaleza alegada" (Tribunal Supremo de Venezuela, Sentencia 1024, 3 de mayo de 2000, Magistrado Ponente José Rafael Tinoco).

20 Carlos Bernal Pulido, "El principio de proporcionalidad como criterio para la aplicación del derecho fundamental a la igualdad”. En Beade/Clérico, Desafíos a la ponderación. Bogotá, 2011, p. 325.

21 Sostuvo el Tribunal Constitucional de Perú que se trata de grupos que han padecido diferencias que "no solo [son] desventajosas, sino contrarias a la dignidad de la persona humana". Sentencia citada por Landa Arroyo, Los derechos fundamentales en la jurisprudencia del Tribunal Constitucional. Lima, 2010.

22 Roberto Saba, “(Des)igualdad estructural”. En Gargarella/Alegre, El derecho a la igualdad: aportes para un constitucionalismo igualitario. Buenos Aires, 2007; Roberto Saba, "El Principio de Igualdad en el Diálogo entre el Derecho Constitucional y el Derecho Internacional”. En Capaldo/Sieckmann/Clérico, Internacionalización del Derecho Constitucional. Constitucionalización del Derecho Internacional. Buenos Aires, 2012.

23 Por ejemplo, en el caso una mujer que inicia una acción de tutela porque no se le permitió ingresar a una disco por su color de piel (negra). La Corte Constitucional de Colombia resuelve el caso alegando las pautas o condiciones del trato diferencial (test de igualdad): "El principio de igualdad consagrado en el artículo 13 de la Carta permite conferir un trato distinto a diferentes personas siempre que se den las siguientes condiciones: que las personas se encuentren efectivamente en distinta situación de hecho; que el trato distinto que se les otorga tenga una finalidad; que dicha finalidad sea razonable, vale decir, admisible desde la perspectiva de los valores y principios constitucionales; que el supuesto de hecho - esto es, la diferencia de situación, la finalidad que se persigue y el trato desigual que se otorga- sean coherentes entre sí o, lo que es lo mismo, guarden una racionalidad interna; que esa racionalidad sea proporcionada, de suerte que la consecuencia jurídica que constituye el trato diferente no guarde una absoluta desproporción con las circunstancias de hecho y la finalidad que la justifican” (Sentencia T-1090/05). Considera que debe existir la aplicación de un test estricto de igualdad. Existe una "categoría sospechosa" pues "en varias oportunidades y por medios diferentes, las autoridades de la República aceptan que la población afrocolombiana o afrodescendiente ha sido objeto de sometimiento histórico, de menosprecio cultural y de abandono social".

24 Así, la Corte Constitucional Colombiana en la sentencia T-371/00 ha dicho que se requieren: "políticas o medidas dirigidas a favorecer a determinadas personas o grupos, ya sea con el fin de eliminar o reducir las desigualdades de tipo social, cultural o económico que los afectan, bien de lograr que los miembros de un grupo subrepresentado, usualmente un grupo que ha sido discriminado, tengan una mayor representación”. En el mismo sentido, el Tribunal Constitucional de Perú, Sentencia 05540-2007-AA, FJ. 8, 9.

25 Retomamos de N. Fraser las categorías de redistribución y reconocimiento. Ver Nancy Fraser, "Social Justice in the Age of Identity Politics: Redistribution, Recognition, and Participation”. En Fraser-Honneth, Redistribution or recognition?: A political-philosophical Exchange. Nueva York, 2003. 
26 “Campos en los cuales han de tomarse medidas para dar mayor Vigencia a los derechos humanos, de conformidad con la Declaración Americana de los Derechos y Deberes del Hombre y la Convención Americana sobre Derechos Humanos, I. La realización de los derechos económicos, sociales y culturales en la región.” (CIDH, Informe Anual 1993, Capítulo V)

27 Se trata de una desigualdad cultural o simbólica, arraigada en los patrones sociales dominantes en una sociedad desde los que se interpreta con pretensión de "uniformidad", por ejemplo, cuál es la forma de matrimonio que debe ser reconocida sin que la voz concreta de quienes tienen una orientación sexual diferente y diversa sea escuchada en el proceso de decisión (así, ejemplos de este tipo de injusticia son la dominación cultural, el no reconocimiento y el irrespeto e incluye la discriminación a lesbianas, gays, travestis, personas trans, bisexuales, entre otros).

28 Por ejemplo, en el caso de matrimonio entre personas del mismo sexo, la opción de formas alternativas de reconocimiento de derechos — como la unión civil — no alcanza a satisfacer el principio de igualdad, puesto que, en realidad, es una forma sutil de afirmar la diferencia entre personas en función de su orientación sexual.

29 Sobre discriminación interseccional, v., entre otros, v.: Kimberlé, Crenshaw, "Intersectionality, Identity Politics, and Violence Against Women of Color”, en: Stanford Law Review, Núm. 43, 1999, pp.1241-1299; Manuel, Góngora Mera, "Derecho a la salud y discriminación interseccional: Una perspectiva judicial de experiencias latinoamericanas”. En: Clérico/Ronconi/Aldao, Martín (eds.): Tratado de Derecho a la Salud, Buenos Aires, 2013.

30 Mario Pecheny y Rafael de la Dehesa, "Sexualidades y políticas en América Latina: el matrimonio igualitario en contexto”. En Aldao/Clérico, Matrimonio igualitario: perspectivas sociales, políticas y jurídicas. Buenos Aires, 2010.

31 Corte Suprema de Justicia Argentina, Repetto, Inés M. c. Provincia de Buenos Aires s/ Acción de Inconstitucionalidad, 08/11/1988, en Fallos: 311:2272.

32 Corte Suprema de Justicia Argentina, Calvo y Pesini, Rocío v. Provincia de Córdoba, 24/02/1998, Fallos: $321: 194 / 201$.

33 Corte Suprema de Justicia Argentina, Gottschau, Evelyn P. c/Consejos de la Magistratura de la Ciudad Autónoma de Buenos Aires s/ amparo sentencia del 08/08/2006.

34 “Art. 10. En la solicitud los postulantes deben acreditar el cumplimiento de los requisitos legales previstos para el cargo al que aspiren... 10.1.4. si es argentino nativo o naturalizado."

35 Ver más adelante.

36 Guillermo Treacy, "La utilización de categorías sospechosas como técnica para controlar la discriminación hacia los extranjeros". Jurisprudencia Argentina, 2006-IV-603.

37 Los migrantes de países limítrofes (de Bolivia, Brasil, Chile, Paraguay y Uruguay) y de no limítrofes (Perú) suelen ser maltratados desde el discurso dominante (muchas veces impulsado desde los discursos de ciertos medios de comunicación que en forma más o menos solapada le suele imputar cierto aumento de la "delincuencia y la inseguridad”), así suelen ser llamados "bolitas”, "brasucas”, “chilotes”, "paraguas”, "perucas” y “yoruguas”. Suelen sufrir detenciones arbitrarias por la sola "portación de cara”, explotación laboral, denegación de acceso a la atención sanitaria, educación y vivienda. V. Waldo Villalpando, La discriminación en la Argentina: diagnóstico y propuestas. Buenos Aires, 2006, p. 168 y s.

38 "Artículo $13 .^{\circ}$ Todas las personas nacen libres e iguales ante la ley, recibirán la misma protección y trato de las autoridades y gozarán de los mismos derechos, libertades y oportunidades sin ninguna discriminación por razones de sexo, raza, origen nacional o familiar, lengua, religión, opinión política o filosófica... Artículo $100{ }^{\circ}$ Los extranjeros disfrutarán en Colombia de los mismos derechos civiles que se conceden a los colombianos. No obstante, la ley podrá, por razones de orden público, subordinar a condiciones especiales o negar el ejercicio de determinados derechos civiles a los extranjeros..."

39 Sentencia T-768/98. En la Sentencia T-123/11 se cuestiona la validez de los arts. 8, 12, 30, 47 y 66 (parciales) del Decreto Ley n. 356, de 1994, "por el cual se expide el Estatuto de Vigilancia y Seguridad Privada”. 
Específicamente los arts. 12 y 47 son cuestionados pues establecen que los socios de las empresas de vigilancia y seguridad privada deben ser personas naturales y de nacionalidad colombiana, excluyendo concretamente a los extranjeros y a las personas jurídicas como potenciales socios de las empresas de vigilancia y seguridad privada. La Corte, retomando su jurisprudencia anterior afirma que "la intensidad del examen de igualdad sobre casos en los que estén comprometidos los derechos de los extranjeros dependerá del tipo de derecho y de la situación concreta por analizar". Así, concluye que si bien los arts. 12 y 47 de la norma demandada establecen un tratamiento diferencial que limita el ejercicio de algunos derechos y libertades, este se encuentra constitucionalmente justificado por cuanto persigue fines admisibles y para alcanzarlos utiliza medios razonables y proporcionales. A este fin, retoma la importancia del servicio de seguridad privada en Colombia, manifestando que "su ejercicio está ligado a la utilización de la fuerza en sus diversas manifestaciones, donde el manejo de armas de fuego y de otros implementos ligados a la seguridad hace que el riesgo de atentar contra la vida e integridad de seres humanos o de afectar sus bienes materiales esté siempre latente. En otras palabras, la vigilancia y seguridad privada es una actividad que por su naturaleza involucra elevadas dosis de riesgo social... por lo tanto se encuentra sujeta a la inspección, control y vigilancia del Estado...”.

40 Sin embargo, puede leerse en este sentido el caso "Reyes Aguilera, D. c. Estado Nacional", resuelto por la CSJ Argentina el 4 de septiembre del 2007. Asimismo, respecto de la distinción entre hombre y mujeres para adquirir la nacionalidad, v. Corte IDH, Opinión Consultiva 4/84 de 19 de enero de 1984 Propuesta de Modificación a la Constitución Política de Costa Rica Relacionada con la Naturalización.

41 Pablo Asa y Pablo Ceriani Cernadas, "Migrantes, derechos sociales y políticas públicas en América Latina y el Caribe: La universalidad en juego”. En Pilar Arcidiácono [et.al.] (coords.). Derechos Sociales: justicia, política y economía en América Latina. Bogotá, 2010, p. 334.

42 Corte IDH, Opinión Consultiva OC-18/03, de 17 de septiembre de 2003, solicitada por los Estados Unidos Mexicanos “Condición Jurídica Y Derechos De Los Migrantes Indocumentados”.

43 En el Amparo en revisión 169/2008. Karina Andrea Smidt, del 23 de abril de 2008, la Primera Sala de la Suprema Corte de Justicia de México resolvió que "al otorgar un trato diferenciado para los extranjeros respecto de los nacionales, las autoridades migratorias por requerir solo a aquéllos la autorización de la Secretaría de Gobernación para poder laborar y para que se les otorgue cierta situación migratoria respecto a su estancia en el país, no violan el principio de igualdad ante la ley, en relación con la garantía de libertad de trabajo. [Sin embargo]... las autoridades migratorias deben fundamentar y motivar cuidadosamente las resoluciones por las cuales niegan a un extranjero el cambio de característica migratoria en un sentido que le permitiría desempeñar actividades remuneradas en el país, pues solo así podrá determinarse... si aquéllas están ejerciendo legítimamente el margen de apreciación concedido por la Ley ... o si están obrando en forma arbitraria y abusiva. IUS 2007 Jurisprudencia y Tesis Aisladas desde Junio 1917 hasta Diciembre de 2007. Mexico Suprema Corte de Justicia de la Nación, Poder Judicial de la Federación".

44 Pablo Asa y Pablo Ceriani Cernadas, "Migrantes, derechos sociales y políticas públicas en América Latina y el Caribe: La universalidad en juego”. En Pilar Arcidiácono [et.al.] (coords.). Derechos Sociales: justicia, política y economía en América Latina. Bogotá, 2010, p. 341.

45 Al respecto, v. Pablo Asa y Pablo Ceriani Cernadas, "Migrantes, derechos sociales y políticas públicas en América Latina y el Caribe: La universalidad en juego”. En Pilar Arcidiácono [et.al.] (coords.). Derechos Sociales: justicia, política y economía en América Latina. Bogotá, 2010.

$46 \mathrm{Al}$ respecto, sostuvo la Corte IDH que "las primeras grandes migraciones de haitianos hacia la República Dominicana ocurrieron durante el primer tercio del siglo 20, cuando alrededor de 100 mil personas se trasladaron a los campos azucareros de aquel país... Muchos migrantes haitianos pasaron a vivir de forma permanente en la República Dominicana, constituyeron familia en este país y ahora viven con sus hijos y nietos (segunda y tercera generación de dominicanos de ascendencia haitiana), quienes nacieron y han vivido en la República Dominicana...". Sin embargo, "la mayoría de los haitianos y dominicanos de ascendencia haitiana en la República Dominicana viven en condiciones de pobreza en zonas conocidas como bateyes, que consisten en asentamientos de trabajadores agrícolas, que se ubican en torno a las plantaciones de caña de azúcar. En esos lugares los servicios públicos básicos son escasos...”.

47 Corte IDH, Caso de las Niñas Yean y Bosico vs. República Dominicana, Sentencia de 8 de septiembre de 2005 , párrafo 240 . 
48 La minoría formada por los jueces Highton y Lorenzetti sostuvo que la distinción era constitucional ya que el otorgamiento de una "pensión por Invalidez" constituye una facultad discrecional del Congreso, órgano que está facultado para imponer distintos requisitos y condiciones. Para un análisis crítico, v. Gargarella Roberto "Cómo no debería pensarse el derecho a la igualdad. Un análisis de las opiniones disidentes en el fallo 'Reyes Aguilera”, en JA 2007-IV-731.

49 Respecto de población indígena, v. Capítulo de este libro Multiculturalismo - Indigenismo, Tatiana Alfonso y Nicolás Espejo.

50 Políticas públicas para el avance de la población afrocolombiana: revisión y análisis, publicación del Proyecto Regional "Población afrodescendiente de América Latina". Programa de las Naciones Unidas para el Desarrollo, 2010, disponible en: <www.afrodescendientes-undp.org>. Acceso el: julio 2011.

51 Marta Rangel, "La población afrodescendiente en América Latina y los objetivos de desarrollo del milenio. Un examen exploratorio en países seleccionados utilizando información censal”. Pueblos indígenas y afrodescendientes de América Latina y el Caribe: información sociodemográfica para políticas y programas. Comisión Económica para América Latina y el Caribe (CEPAL), 2006; Manuel, Góngora-Mera, "Transnational Articulations of Law and Race in Latin America. A Legal Genealogy of Inequality“, desiguALdades.net Working Paper Series, 2012, No. 18, Berlin: desiguALdades.net Research Network on Interdependent Inequalities in Latin America; Lucía Alicia, Aguerre, "Desigualdades, racismo cultural y diferencia colonial", desiguALdades.net Working Paper Series, 2011, Nr. 5, Berlin: desiguALdades.net Research Network on Interdependent Inequalities in Latin America.

52 Fernando Guerrero, "Población indígena y afroecuatoriana en el Ecuador, a partir de la información censal del 2001". Pueblos indigenas y afrodescendientes de América Latina y el Caribe: información sociodemográfica para políticas y programas. Comisión Económica para América Latina y el Caribe (CEPAL), 2006.

53 Sentencia T- 422/96 de la Corte Constitucional Colombiana.

54 En este sentido, art. 7 de la Constitución de Colombia; art. 1 de la Constitución de Ecuador; y Art. 1 de la Constitución de Bolivia.

55 Sentencia T-1090/05 de la Corte Constitucional Colombiana.

56 V. Sentencia T-1090/05 de la Corte Constitucional Colombiana; Marta Rangel, "La población afrodescendiente en América Latina y los Objetivos de Desarrollo del Milenio. Un examen exploratorio en países seleccionados utilizando información censal". Pueblos indígenas y afrodescendientes de América Latina y el Caribe: información sociodemográfica para políticas y programas. Comisión Económica para América Latina y el Caribe (CEPAL), 2006.

57 Acuerdo Superior n. 0024 de 2001: “Artículo 4. La Universidad continuará asignando... un cupo especial en cada programa de formación profesional, para bachilleres procedentes de comunidades afrocolombianas con asiento en el departamento del Magdalena. Artículo 5. Los aspirantes inscritos para competir por el cupo especial descrito en el artículo anterior, deben ser presentados por las autoridades comunitarias debidamente reconocidas... y competirán con los demás bachilleres inscritos bajo la condición de afrocolombiano, por el cupo especial. El ganador será, entre todos ellos, el que obtenga el puntaje más alto en el examen de admisión dentro del programa para el cual se inscribió el aspirante, siempre y cuando el resultado en el mismo sea igual o superior al 30\% del valor total establecido".

58 Dispuesto por el art. 2. ${ }^{\circ}$ de la Resolución n. 507/95.

59 Werle, Denílson et. al. "El horizonte de la política - Brasil y la agenda contemporánea de investigación en el debate internacional”. México: Centro de Investigaciones y Estudios Superiores en Antropología Social (Ciesas).

60 Werle, Denílson et. al. "El horizonte de la política - Brasil y la agenda contemporánea de investigación en el debate internacional”, México: Centro de Investigaciones y Estudios Superiores en Antropología Social (Ciesas).

61 Debe tenerse presente que el sistema de decisiones de Brasil es individual. Obtenidos todos los votos, la decisión final es la suma de los votos individuales. 
62 Por ejemplo, regulan solo el acceso a la universidad, pero nada dicen de las condiciones en las que los afrodescendientes pueden llegar a ella. Nos referimos por ejemplo a que muchos integrantes de las comunidades afro deben dejar sus estudios básicos para salir a trabajar por la situación de pobreza extrema en la que se encuentran.

63 Rodolfo Arango, "Diversidad étnica, igualdad y derechos humanos". Revista de Antropología y arqueología, v. 34,2003 , p. 25

64 V. Treacy, Guillermo, “Categorías sospechosas y control de constitucionalidad”. Lecciones y Ensayos, Dossier de Igualdad, Facultad de Derecho/UBA, Buenos Aires, 2011. Agrega incluso que algunos ordenamientos locales incluyen a la edad como motivo especialmente prohibido de discriminación. Tal es el caso del art. 11 de la Constitución de la Ciudad Autónoma de Buenos Aires. El Tribunal Superior de Justicia de la Ciudad tuvo oportunidad de referirse a la edad, fijada como requisito restrictivo de derechos, en el caso "Salgado, Graciela B. c/ GCBA", del 21/11/2001 (disponible en: <www.tsjbaires.gov.ar>). Para una crítica de la aplicación de este análisis a las distinciones por edad, véase: Sebastián Schvartzman, “¿Debe ser la edad considerada una categoría sospechosa?”. La Ley 2002-F-455.

65 Fallos 307:1963, del 15/10/1985.

66 V. comentario crítico al fallo en: Clérico, L., "Las ausencias argumentativas de la Corte Suprema en el caso 'Franco': sobre las limitaciones a las concesiones de los registros públicos notariales provinciales”. Lexis Nexis Jurisprudencia Argentina. Buenos Aires: 2003, v. JA n. II, p. 40-54.

67 Ver, entre otras, las sentencias SU-642 de 1998, fundamento 6 y SU-337 de 1999, fundamento 26.

68 Dispuesto por el art. 2. ${ }^{\circ}$ de la Resolución n. 507/95. Así, la sentencia C-676 de 1998, MP José Gregorio Hernández Galindo,

69 Sandra Huenchuan (ed.), Envejecimiento, derechos humanos y politicas públicas. Comisión Económica para América Latina y el Caribe (CEPAL), Santiago de Chile, abril de 2009

70 Corte Constitucional de Ecuador, sentencia 007-10-SIN-CC.

71 CSJN, "Reynoso, Nilda Noemí c. Instituto Nac. de Servicios Sociales para Jubilados y Pensionados", "Parraga Alfredo c/ INSSJ y P (ex PAMI) s/amparo” y “Papa Estela Ángela c/ I.N.S.S.J y P. s/amparo”, todos del 16 de mayo de 2006.

72 Una madre comunitaria es aquella que se ocupa de cuidar los niños que, por alguna razón, han sido separados de sus familia por el Estado.

73 La Corte IDH ha señalado en su jurisprudencia constante v.g., caso Villagrán Morales y Otros ("Niños de la Calle”), 1999, párrs. 144 a 146; caso Bulacio, 2003; caso Myrna Mack Chang, 2003; caso del Instituto de Reeducación del Menor, 2004; caso Huilca Tecse, 2005. Caso de la Masacre de Pueblo Bello, párr. 120; Caso de la "Masacre de Mapiripán”, párr. 232; Caso Huilce Tecse. Sentencia, de 3 de marzo de 2005. Serie C n. 121, párr. 66; Caso "Instituto de Reeducación del Menor". Sentencia de 2 de septiembre de 2004. Serie C n. 112, párr. 158; Caso de los Hermanos Gómez Paquiyauri. Sentencia de 8 de julio de 2004. Serie C n. 110, párr. 129; Caso 19 Comerciantes, párr. 153; Caso Myrna Mack Chang, párr. 153; Caso Juan Humberto Sánchez, párr. 110; Caso Bámaca Velásquez. Sentencia de 25 de noviembre de 2000. Serie C n. 70, párr. 172.

74 Votos concurrentes de los jueces A. A. Cançado Trindade y A. Abreu Burelli.

75 Corte Suprema argentina caso Maldonado del 23/11/2004, Fallos 327:5210; caso Lifschitz del 15/6/2004, Fallos 327:2413.

76 OMS Informe Mundial sobre la Discapacidad, 2011

77 OMS Informe Mundial sobre la Discapacidad, 2011.

78 OMS Informe Mundial sobre la Discapacidad, 2011. 
79 Respecto de Argentina, v. <www.rals.org.ar/jurisprudencia.htm>.

80 OG n. 5 Comité DESC de la ONU.

81 Ver al respecto la sentencia T-823/1999.

82 Sentencia T-595/2002, T-983/2002, T-065/I003, T-401/2003.

83 Sentencia T-401/2003.V. las sentencias T-427/1992, T-441/1993. Sobre el tema de los beneficios del retén social en favor de los discapacitados, pueden consultarse, entre otras, las sentencias T-792/2004, T-602/2005, T$1031 / 2005$, T-626/2006.

84 En sentido similar se pronunció en la sentencia dictada el 13 de febrero del 2009 sobre el amparo interpuesto por Delroy Morgan González, persona discapacitada que usa silla de ruedas, contra la Municipalidad de Guácimo, por haber violado su derecho a la libertad de tránsito debido al mal estado de las aceras y falta de rampas.

85 Sentencia T-823/1999.

86 OMS Informe Mundial sobre la Discapacidad, 2011.

87 Res. n. 2009-00938.

88 Res. n. 2009002773

89 CSJN-Fallos 327:2413, año 2004

90 Ver la sentencia reciente de la Corte Suprema argentina recaída en el caso “Quisberth Castro” (2012) en el que condenó al Gobierno de la Ciudad Autónoma de Buenos Aires a realizar acciones positivas adecuadas y suficientes, para que el niño que padecía una discapacidad grave y vivía con su madre en la calle, tengan acceso a una vivienda digna. Laura, Clérico, "Sobre la insuficiencia desde el prisma de la igualdad real: pistas para evaluar una violación del derecho a la vivienda", Jurisprudencia Argentina, Buenos Aires, 2012; Gustavo, Caramelo Díaz, "El derecho a una vivienda adecuada según la Corte Suprema argentina”, Jurisprudencia Argentina, Buenos Aires, 2012.

91 V. C-174/04 donde se sostuvo que si bien las acciones positivas se basan en categorías sospechosas es válido por su función compensadora respecto de las personas con discapacidad.

92 En el mismo sentido, se resolvieron las sentencias T-1134/2000 y T-974/2010.

93 En sentencia T-513/1999, la Sala Sexta de Revisión reiteró este precedente al revisar los fallos proferidos dentro del trámite de la acción de tutela presentada en favor de un menor que padecía parálisis de las piernas e hidrocefalia, y a quien las directivas de una institución educativa le impedían el ingreso al plantel. Este fallo destacó que el principio de integración obedece a claros preceptos de nuestro ordenamiento jurídico, como el art. 47 de la Constitución Política y las Leyes 115 de 1994 y 361 de 1997. De igual manera, en sentencia T-1482/2000, la Corte dio aplicación al principio de integración en el caso de varios menores cuyas aulas especiales fueron cerradas. La institución educativa en la que se encontraban ofreció, entonces, como alternativa para los niños su integración a las aulas regulares, lo cual, en criterio de sus padres, constituía una vulneración del derecho a la educación especial de los menores. La Sala Segunda de Revisión señaló que la normatividad colombiana que rige la materia encontró un punto intermedio al establecer la integración, pero con apoyo especializado, tal y como se dio en el caso puesto en su conocimiento, lo cual le permitió colegir que no se presentaba vulneración de derecho fundamental alguno de los menores en cuyo nombre había sido invocada la acción de tutela.

94 OMS Informe Mundial sobre la Discapacidad, 2011.

95 Corte Suprema de Justicia Argentina, sentencia del 24/10/2000 - Fallos: 323:3229.

96 “Cambiaso Péres de Nealón c. CEMIC". Corte Suprema de Justicia argentina, 28/08/2007, en especial, v. el voto concurrente de Fayt y Maqueda quienes se refirieron también a la posición de debilidad contractual de la persona con discapacidad en el contrato de medicina prepaga. 
97 Mario Pecheny y Rafael de la Dehesa, "Sexualidades y políticas en América Latina: el matrimonio igualitario en contexto”. En Aldao/Clérico, Matrimonio igualitario: perspectivas sociales, políticas y jurídicas. Buenos Aires, 2010, p. 35.

98 Aldao/Clérico, Matrimonio igualitario: perspectivas sociales, políticas y jurídicas. Buenos Aires, 2010.

99 En Argentina el caso CHA, en Colombia las sentencias T-098/96 y SU-623/01 y en Chile el caso Atala entre otros.

100 Corte Suprema de Justicia argentina, Asociación lucha por la identidad travesti-transexual c. Inspección General de Justicia, sentencia del 21/11/2006.

101 Laura Clérico, "El matrimonio igualitario y los principios constitucionales estructurantes de igualdad y/o autonomía”. En Aldao/Clérico, Matrimonio igualitario: perspectivas sociales, políticas y jurídicas, Buenos Aires, 2010, p. 166 y 167.

102 Sentencias C-098/96 y SU-623/01.

103 Freyre Alejandro c. GCBA s/ Amparo (art. 14 CCABA), Juzgado 1ra Inst. En lo Contencioso Adm. y Trib. n. 15 de la Ciudad Autónoma de Buenos Aires, noviembre de 2009, párrafo VII. En adelante, caso Freyre.

104 Caso Freyre, párrafo IX.

105 Caso Freyre, párrafo XIX.

106 Si bien llegaron a la Corte Suprema de Justicia argentina casos donde se solicitaba la inconstitucionalidad de los arts. del Código Civil que impedían el matrimonio igualitario, los mismos no fueron resueltos antes de la sanción de la Ley n. 26.618 .

107 Laura Clérico, "El matrimonio igualitario y los principios constitucionales estructurantes de igualdad y/o autonomía”. Aldao/Clérico, Matrimonio igualitario: perspectivas sociales, políticas y jurídicas. Buenos Aires, 2010, p. 163.

108 El resaltado es propio.

109 Laura Clérico, "El matrimonio igualitario y los principios constitucionales estructurantes de igualdad y/o autonomía”. Aldao/Clérico, Matrimonio igualitario: perspectivas sociales, políticas y jurídicas. Buenos Aires, 2010, p. 166.

110 Laura Clérico, "El matrimonio igualitario y los principios constitucionales estructurantes de igualdad y/o autonomía”. Aldao/Clérico, Matrimonio igualitario: perspectivas sociales, políticas y jurídicas. Buenos Aires, 2010.

111 Durante el proceso de evaluación de este trabajo el caso ha sido resuelto por la Corte IDH: Caso Atala Riffo y niñas vs. Chile, sentencia del 24 de febrero de 2012, Serie C-239. V. sobre esta sentencia los trabajos publicados en: Bogdandy/Piovesan/Morales, Igualdad y Orientación Sexual. El Caso Atala de la Corte Interamericana de Derechos Humanos y su Potencial, Editorial Porrúa, S.A., Mexiko, 2012

112 CEPAL, Panorama social de América Latina 2010, 32\% y 12\% respectivamente.

113 "Cuando los sectores más vulnerables de la sociedad no tienen acceso a los elementos básicos para la supervivencia que les permitirían salir de su situación, se está contraviniendo voluntariamente o se está condonando la contravención del derecho a ser libre de toda discriminación y los consiguientes principios de igualdad de acceso y equidad en la distribución, y el compromiso general de proteger a los elementos vulnerables de la sociedad." (Informe CIDH Paraguay, 1993)

114 En esta línea, ver el trabajo de reconstrucción de la noción de "mínimo vital” dirigida por Rodolfo Arango y Julieta Lemaitre, en Jurisprudencia constitucional sobre el derecho al mínimo vital, Estudios Ocasionales, Centro de Investigaciones Socio-Jurídicas (CIJUS), Facultad de Derecho, Universidad de los Andes, Bogotá, 2002. 
115 Ezequiel Nino, "La discriminación menos comentada". En Roberto Gargarella, La Constitución en 2020: 48 propuestas para una sociedad igualitaria. Buenos Aires, 2011, p. 49.

116 Sección 5.2, párrafo 17.

117 Sección 8.1.

118 Sección 5.2 , párrafo 17.

119 Ver María del Carmen Verdú, Represión en democracia: de la "primavera alfonsinista" al "gobierno de los derecho humanos". Buenos Aires, 2009.

120 Corte IDH, Bulacio v. Argentina, sentencia 18/09/2003.

121 Corte IDH, Servellón García y otros c. Honduras, sentencia del 21 de septiembre del 2006, párr. 95.

122 IDH, Servellón García y otros c. Honduras, sentencia del 21 de septiembre del 2006, párr. 112.

123 Juzgado en lo contencioso, administrativo y tributario de la CABA n. 11, sentencia del 10 de julio del año 2006.

124 Estos contenedores son espacios diseñados para transportar mercaderías o guardar materiales de construcción de obras. Los módulos se caracterizan por ser espacios rectangulares reducidos, están construidos en chapa y revestidos en su interior por corlock, sus puertas se cierran con candados, tienen poca ventilación y aireación, y mínimo aislamiento térmico.

125 Nino/Maurino, "Judicialización de las políticas públicas de contenido social. Un examen a partir de los casos tramitados en la Ciudad de Buenos Aires”. En Abramovich/Pautassi (Comp.). La revisión judicial de las políticas sociales. Estudio de casos. Buenos Aires, 2009, p. 177.

126 Párr. XXII.

\section{Laura Clérico}

Instituto de Investigaciones Jurídicas y Sociales A.L. Gioja

Facultad de Derecho - Universidad de Buenos Aires Av. Figueroa Alcorta 2263, 10 piso (C1425CKB) Ciudad Autónoma de Buenos Aires - Argentina lauraclericolayahoo.com DE Derecho de LA Universidad de Buenos Aires

\section{Liliana Ronconi}

Facultad de Derecho - Universidad de Buenos Aires Av. Figueroa Alcorta 2263, $1^{\circ}$ piso (C1425CKB)

Ciudad Autónoma de Buenos Aires - Argentina

Imronconiagmail.com

ABogada

Profesora en Ciencias JurídicAs, UNIVERSIDAD DE BUENOS AIRES

EX BECARIA DAAD/ ALEARG

BeCARIA DE DOCTORADo, Universidad de Buenos Aires 
170 : HACIA LA RECONSTRUCCIÓN DE LAS TENDENCIAS JURISPRUDENCIALES EN AMÉRICA LATINA Y EL CARIBE

\section{Martín Aldao}

Facultad de Derecho - Universidad de Buenos Aires Av. Figueroa Alcorta 2263, $1^{\circ}$ piso (C1425CKB) Ciudad Autónoma de Buenos Aires - Argentina maldaolderecho.uba.ar
Dr. en Derecho por la Universidad de Buenos Aires INVESTIGADOR INST. A.L.GIOJA Y DOCENTE DE Derecho Público, facultad de Derecho de LA Universidad de Buenos Aires Becario Posdoctoral CONICET 